\title{
Quantification of SARS-CoV-2 neutralizing antibody by wild-type plaque reduction neutralization, microneutralization and pseudotyped virus neutralization assays
}

\author{
Kevin R. Bewley ${ }^{1 凶}$, Naomi S. Coombes $\mathbb{D}^{1}$, Luc Gagnon ${ }^{2}$, Lorna Mclnroy ${ }^{1}$, Natalie Baker ${ }^{1}$, \\ Imam Shaik ${ }^{1}$, Julien R. St-Jean ${ }^{2}$, Natalie St-Amant ${ }^{2}$, Karen R. Buttigieg ${ }^{1}$, Holly E. Humphries ${ }^{1}$, \\ Kerry J. Godwin', Emily Brunt ${ }^{1}$, Lauren Allen', Stephanie Leung ${ }^{1}$, Phillip J. Brown ${ }^{1}{ }^{1}$, \\ Elizabeth J. Penn ${ }^{1}$, Kelly Thomas $\mathbb{D}^{1}$, Greg Kulnis ${ }^{2}$, Bassam Hallis ${ }^{1}$, Miles Carroll ${ }^{1}$, \\ Simon Funnell ${ }^{1}{ }^{1}$ and Sue Charlton ${ }^{1}$
}

Virus neutralization assays measure neutralizing antibodies in serum and plasma, and the plaque reduction neutralization test (PRNT) is considered the gold standard for measuring levels of these antibodies for many viral diseases. We have developed procedures for the standard PRNT, microneutralization assay (MNA) and pseudotyped virus neutralization assay (PNA) for severe acute respiratory syndrome coronavirus 2. The MNA offers advantages over the PRNT by reducing assay time, allowing increased throughput and reducing operator workload while remaining dependent upon the use of wild-type virus. This ensures that all severe acute respiratory syndrome coronavirus 2 antigens are present, but Biosafety Level 3 facilities are required. In addition to the advantages of MNA, PNA can be performed with lower biocontainment (Biosafety Level 2 facilities) and allows for further increases in throughput. For each new vaccine, it is critical to ensure good correlation of the neutralizing activity measured using PNA against the PRNT or MNA. These assays have been used in the development and licensure of the ChAdOx1 nCoV-19 (AstraZeneca; Oxford University) and Ad26.COV2.S (Janssen) coronavirus disease 2019 vaccines and are critical for demonstrating bioequivalence of future vaccines.

Introduction

Coronaviruses are enveloped, positive-sense, single-stranded RNA viruses that belong to the family Coronaviridae. Coronaviruses are known to cause diseases with a spectrum of severity in humans and other animals $^{1,2}$. In December 2019, a new coronavirus emerged that was identified as a member of the Betacoronavirus genus. It was subsequently named severe acute respiratory syndrome coronavirus 2 (SARS-CoV-2) and is the causative agent of coronavirus disease 2019 (COVID-19). The spread of this virus led to a global pandemic affecting millions of people ${ }^{3}$. The search for an effective vaccine for COVID-19 is a global priority. Immunological assays, such as those for neutralizing antibodies, are important for providing information on correlates of protection for vaccine efficacy and data to support regulatory submissions for vaccine licensure.

Development of the protocol

The initial procedure developed was the plaque reduction neutralization test (PRNT), which measures neutralizing antibodies by in vitro virus neutralization. PRNT is considered the gold standard for assessing humoral correlates of protection for many viral diseases ${ }^{4-6}$. In the absence of phase III efficacy data, neutralizing antibody results have a key role in identifying optimal COVID-19 vaccine candidates and will be important in the regulatory licensure process. It is not yet known whether circulating neutralizing antibody levels can be considered a sole measure of protective immunity against COVID-19, but recent successful treatment of severely ill patients with convalescent plasma and monoclonal antibody therapeutics containing high levels of neutralizing antibodies suggest an

${ }^{1}$ National Infection Service, Public Health England, Salisbury, UK. ${ }^{2}$ Nexelis, Laval, Quebec, Canada. ${ }^{凶}$ e-mail: Kevin.Bewley@phe.gov.uk 


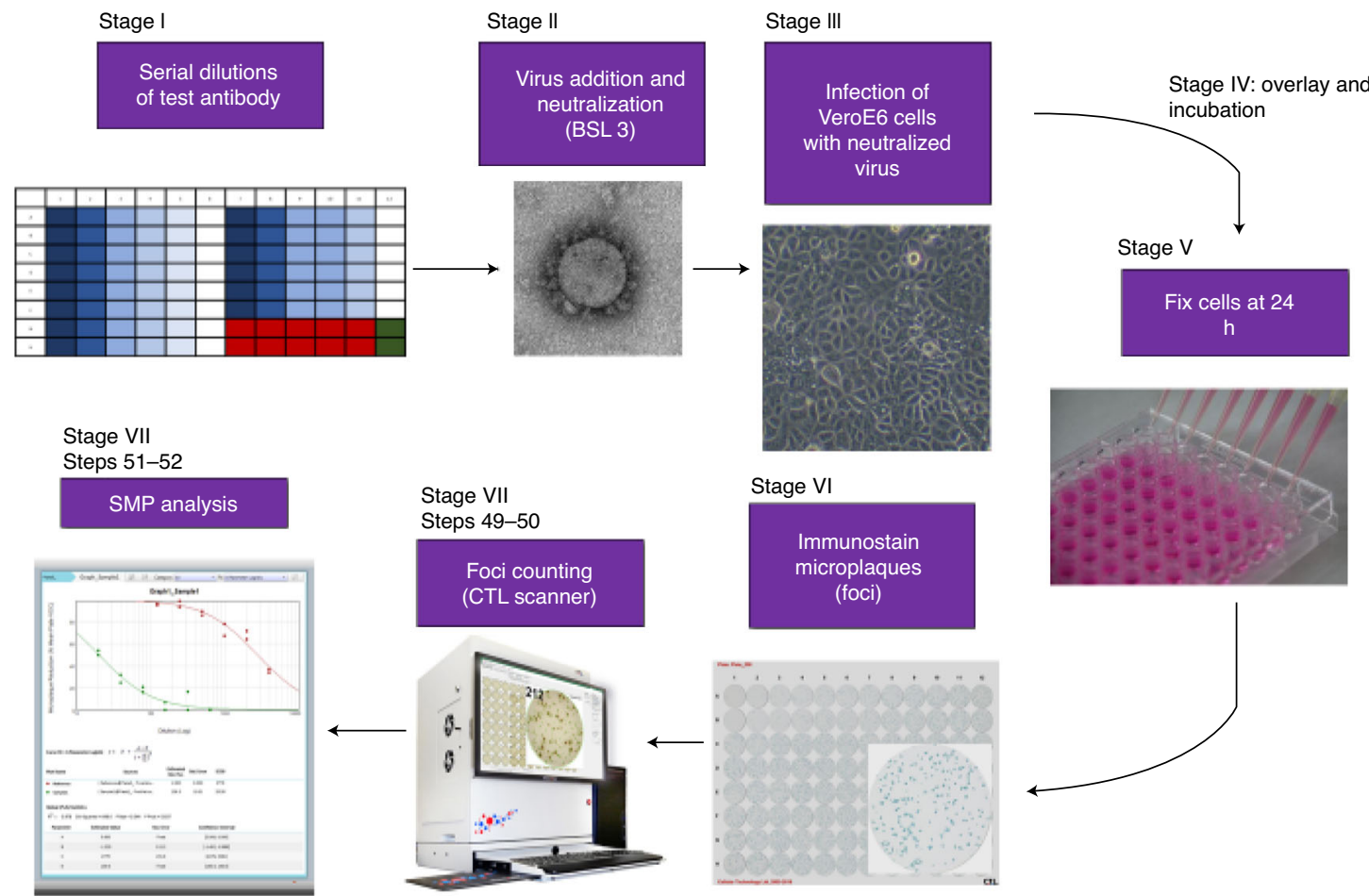

Fig. 1 | General overview of the MNA described in Procedure 2. Serum samples are diluted in a 96-well plate (Stage I), before wild-type SARS-CoV-2 virus is added to the diluted serum at BSL3 and neutralization allowed to occur (Stage II). The neutralized virus is then transferred onto Vero E6 cells (Stage III), allowed to adsorb, overlaid with viscous medium and incubated for $24 \mathrm{~h}$ (Stage IV). Plates are then fixed (Stage V), virus infected foci immunostained (Stage VI) and foci counted (Stage VII). Well counts are then analyzed with SoftMax Pro to determine median neutralization titers of the reference and test sera (Stage VIII).

important role for these antibodies ${ }^{7-10}$. However, PRNT has several limitations that make it unsuitable for large-scale studies of serum samples, such as phase III human clinical vaccine trials. PRNT is technically demanding, has very low throughput, is difficult to automate and, for SARS-CoV-2, has a long turnaround time due to the time taken for the virus to form visible plaques. In addition, the analysis of the count data is typically performed using Excel spreadsheet calculations to determine neutralization titers (e.g., Kärber formula ${ }^{11}$ ) or using free statistical packages such as R to perform Probit regression. These analysis solutions represent obstacles for assay validation, which may lead to difficulties in using the data as part of a regulatory submission. For these reasons, of the three assays presented in this article, only the microneutralization assay (MNA) and pseudotyped virus neutralization assay (PNA) (not the PRNT) have been qualified, as only data produced by these assays and analyzed by the validated version of the SoftMax Pro software are likely to be acceptable to regulatory agencies. The qualification results for the MNA and PNA can be found in Extended Data Figs. 1 and 2, respectively.

To improve on the limitations of the PRNT, an alternative assay called the focus-reduction neutralization test (more commonly known as an MNA) has been developed for other viruses ${ }^{12-14}$. This assay is performed in 96-well plates throughout and uses immunostaining to visualize infected foci, which can be counted using computer-controlled imagers (Fig. 1), substantially increasing assay throughput compared with the manual counting performed in PRNT. A further development of MNA is to replace the hazard group 3 wild-type virus with a hazard group 2 pseudotyped virus to perform a PNA. Pseudotyped viruses consist of nonreplicating genetically modified virions that comprise the structural and enzymatic core of one virus, such as vesicular stomatitis virus (VSV), while bearing the surface proteins of another virus, such as the SARS-CoV-2 spike, and encode a quantifiable reporter gene such as firefly luciferas $\mathrm{e}^{15}$. In the PNA described in this protocol, the pseudotyped virus consists of a VSV that has been engineered to bear the SARS-CoV-2 spike glycoprotein on its surface and replace its $\mathrm{G}$ protein gene with a luciferase reporter. The last 19 amino acids of the spike protein have been deleted, which roughly corresponds to the cytoplasmic tail. 
In this protocol, we describe procedures for performance of the classical PRNT, a newly developed MNA and a PNA for the measurement of SARS-CoV-2 neutralizing antibodies. The National Institute for Biological Standards and Control (NIBSC) has made available the 1st WHO International Standard for anti-SARS-CoV-2 antibody $(20 / 136)^{16}$. In combination with this international antibody standard, we expect these assays to play a pivotal role in the development and licensure of urgently needed COVID-19 vaccines.

\section{Applications}

The MNA and PRNT described in this protocol have been applied to the testing of serum from participants in randomized controlled clinical trials for the ChAdOx1 nCoV-19 (AstraZeneca; Oxford University) and Ad26.COV2.S (Janssen) COVID-19 vaccines ${ }^{17-19}$. They have also been applied to the testing of serum from animal models ${ }^{20,21}$ and vaccine immunogenicity studies ${ }^{22}$. The wild-type assays may also be used with little adaptation to assess the in vitro efficacy of antiviral drugs ${ }^{23}$. All three assays permit the detection and measurement of titers of SARS-CoV-2 neutralizing monoclonal antibodies $^{24,25}$ and could help to elucidate the structural basis of neutralization ${ }^{26}$. These assays form a critical readout for the development and licensure of current and future COVID-19 vaccines and, moving forward, will be a key element in demonstrating the bioequivalence of future vaccines.

\section{Comparisons between the assays}

The PRNT requires $5 \mathrm{~d}$ of incubation to develop countable plaques, whereas, in the MNA and PNA, plates are fixed after only $24 \mathrm{~h}$ incubation; this considerably shortens the turnaround time of these assays. The MNA and PNA are conducted in 96-well plate format throughout, whereas the PRNT is performed in a mixture of 96-well (for the neutralization stage) and 24-well (for the plaque assay) plates. This increases the number of samples that can be tested per operator on any given testing occasion in the MNA and PNA relative to the PRNT. The use of 96-well plates throughout the assay also facilitates increased automation of the washing, staining and reading stages of the assay. Automation is a key factor in reducing operator error and increasing assay precision.

In the MNA, immunostained foci are counted using a computerized counting system and, in the PNA, luminescence of the luciferase reporter is measured with a plate reader; whereas, in the PRNT, operators perform manual plaque counting. This improves accuracy and objectivity of the reading as well as increasing throughput. In the MNA and PNA, count and luminescence measurements, respectively, are analyzed automatically using curve-fitting software, which allows the majority of test samples to have a median neutralizing dose $\left(\mathrm{ND}_{50}\right)$ assigned to them. In addition, the curve-fitting method provides a confidence interval around any result derived from the curve. The software used is GxP compliant, which lends itself to validation in accordance with the Good Clinical Practice (GCP) regulations required by regulatory authorities. In contrast, the most common methods for performing this determination for PRNT and some PNA assays ${ }^{27}$ are use of the Spearman-Kärber or Reed-Muench formulae, both of which require a full neutralization response (0-100\%) and neither of which easily provide confidence intervals. These traditional calculations are generally carried out by hand or with the aid of a spreadsheet, representing additional challenges for assay validation to meet the requirements of regulators.

As wild-type virus contains the complete SARS-CoV-2 replicative machinery, both PRNT and MNA can be adapted to assess the efficacy of antiviral compounds, whereas the PNA is appropriate only for measuring neutralization activity of serum or monoclonal antibody-based therapeutics.

\section{Limitations}

Limitations of the PRNT are that it is slow to perform, has low throughput and is technically demanding. In addition, both the wild-type MNA and PRNT require access to Biosafety Level 3 (BSL3) facilities and suitably trained staff, whereas the PNA can be conducted in a BSL2 facility. MNA and PNA correlate well with the 'gold standard' PRNT when tested with a panel of convalescent human serum; live virus PRNT with MNA (Pearson $r=0.963 ; P<0.001$ ) and PRNT with PNA (Pearson $r=0.862 ; P<0.001$ ) (Extended Data Figs. 3 and 4). During qualification, assay performance is assessed and documented for key performance metrics, e.g., specificity, linearity, bias, precision and limits of quantification. Both the MNA and the PNA have been qualified and will be utilized in regulatory submissions. However, as the pseudovirus used in PNA contains only the SARSCoV-2 spike antigen and not the full complement of viral antigens, there is a risk that the PNA might fail to correlate well with the wild-type assays for some vaccine candidates, particularly those 
containing non-spike subunits of SARS-CoV-2. It is therefore crucial that, for each novel vaccine candidate, serum responses are correlated between MNA and PNA before transferring serum antibody assessments over to the PNA.

A potential limitation of all neutralization assays utilizing wild-type virus relates to the testing of plasma instead of serum derived from clotted whole blood, as plasma is often derived from whole blood that has been collected into tubes containing heparin as an anticoagulant. There have been reports that heparin is an effective inhibitor of SARS-CoV-2 entry into cells, and therefore there is a risk that this sample type might give rise to erroneous results from these assays ${ }^{23,28}$. Other common anticoagulants have not been reported to exhibit nonspecific antiviral activity.

A final limitation of the PNA is that the assay is appropriate only for measuring neutralization activity of serum or monoclonal antibody-based therapeutics, whereas both wild-type virus assays can be adapted to assess the efficacy of other antiviral compounds. This is because the pseudovirus does not contain the coronavirus replicative machinery that such compounds are directed against.

\section{Alternative methods}

All measurements of neutralizing antibody titers are generally performed by PRNT, some form of the MNA, or assays using pseudotyped viruses (e.g., the PNA). PRNT tests generally follow the procedure described here with only minor changes, mainly to the source of the wild-type virus, the semi-solid overlay used (agarose, methylcellulose or AviCell) and the method of analysis. Of these, only the method of analysis is worthy of note. As discussed earlier, methods such as Reed-Muench and Spearman-Karber are often still used to estimate median neutralization doses. In the past, this was due to their ease of calculation; however, curve-fitting methods have now been demonstrated to provide more accurate results ${ }^{29}$, and their computation no longer presents a barrier. The primary advantage of PRNT over other methods is the ability to detect more subtle changes, such as those to plaque morphology, in response to a serum sample, antibody or therapeutic, as well as a reduction in total plaque number. For example, antibody enhancement may cause plaques to appear larger than normal, or certain types of incomplete neutralization may cause a reduction in plaque size.

Large increases in scale and sample throughput can be achieved by replacing the PRNT with an MNA. In addition, as MNA is performed in a 96-well format, the assays are more amenable to automation of several assay steps. The two main types of MNA differ in the method of readout; some assays (such as those presented here) are read by counting immunostained foci (spots), whereas others are read on an ELISA reader measuring a colorimetric dye such as o-phenylenediamine $\mathrm{e}^{30}$. The advantage of foci counting is that microbial contamination of samples or other mishandling causing cell monolayer damage can be seen during the plate quality control stages of the assay; whereas a colorimetric assay lacks this opportunity to reject the well or sample containing the error, leading to an aberrant absorbance reading. The advantages of the colorimetric methods are that they are generally faster to read, require less expensive equipment to perform measurements, and setting up the curve-fitting software is more straightforward. In the MNA presented here, the primary focus detection antibody is directed at the SARS-CoV-2 spike receptor binding domain, which is presented on the surface of infected cells; whereas, in other assays, the primary antibody is directed against the viral nucleocapsid ${ }^{30}$, which requires the staining procedure to have an additional cell-permeabilization step that increases assay time. The advantage of using a primary antibody against nucleocapsid is that, if one is working with virus variants with many mutations in the spike protein, it is conceivable that the anti-spike antibodies may no longer bind to the spike; however, this is less likely to occur to the nucleocapsid, as it is not under the same immune pressure in the host.

All wild-type assays suffer from the limitation of requiring BSL3 facilities and highly trained staff to perform them. PNAs allow neutralization assays to be performed in a standard BSL2 laboratory. These assays retain the advantages of the MNA, of being more scalable and having higher throughput than the PRNT. The readout of the PNA is luminance, which has the same advantages and disadvantages discussed for colorimetric methods in the MNA above. Median neutralizing doses can be determined using in-house Excel calculations (e.g., Reed-Muench method) or curve-fitting functions in off-the-shelf statistical packages such as GraphPad Prism ${ }^{27,31}$, but these approaches are unlikely to be acceptable to vaccine licensing agencies. It is preferable, as presented here, to perform calculations within a GxP validated version of curve-fitting software such as SoftMax Pro. 


\section{Box 1 | Sample-preparation procedure for all assays Timing $1 \mathrm{~h}$}

\section{Procedure}

$\triangle$ CRITICAL Before assessment of neutralizing antibody activity in serum samples, it is essential to inactivate components of the complement system as they are known to interfere with these assays.

!CAUTION Appropriate national laws and institutional regulatory board ethical guidelines must be followed and informed consent obtained from patients for the use of human serum in these protocols

1 Heat the water bath to $56^{\circ} \mathrm{C}\left( \pm 1^{\circ} \mathrm{C}\right)$, and confirm with a calibrated thermometer.

2 Briefly centrifuge serum samples at $2,000 \mathrm{~g}$ for $10-30 \mathrm{~s}$ to ensure that the entire sample is collected in the bottom of each tube.

3 Place the tubes containing the serum into the water bath for 30-40 min.

4 Mark tubes to confirm heat inactivation has been performed.

DAUSE POINT Proceed immediately to testing or freeze serum until required $\left(\leq-16^{\circ} \mathrm{C}\right)$ for several months at $\leq-16^{\circ} \mathrm{C}$ or years at $\leq-65^{\circ} \mathrm{C}$.

\section{Overview of the procedures}

For all neutralization assays described here, the serum must first be heat-treated to inactivate complement using the method described in Box 1. For both wild-type virus assays, PRNT (Procedure 1) and MNA (Procedure 2), a stock of virus needs to be produced as described in Box 2. For the PRNT, the wild-type virus stock is subjected to a rough sighting to estimate the dilution at which to prepare the virus, followed by the fine sighting (Box 3). Once a given virus stock has been sighted into the assay in this manner, samples can be analyzed by the PRNT by following the instructions in Procedure 1. A similar process is used to test a new virus stock in the MNA but can be more simply performed by the semifine sighting (Box 4), which includes regression analysis to determine the working dose for the assay. Once the virus has been sighted into the MNA, samples can be analyzed by following the instructions in Procedure 2. Resighting of the PRNT or MNA would only be required when a new stock of wild-type virus is produced or if the virus-only control (VOC) counts were outside the specified range for the assay.

For the PNA (Procedure 3), stocks of pseudovirus should be produced by following the procedure in Box 5. New virus stocks should be subjected to the sighting procedure (Box 6). Once the optimal pseudotyped virus dilution for a given stock is known, Procedure 3 can be started. Resighting would be required in the event of a new batch of pseudotyped virus being produced or if the VOCs (pseudotyped virus control; PC) luminescence measurements were outside the specified range.

\section{Experimental design}

To perform the procedures described in this protocol, commercial individual and/or pooled human serum containing SARS-CoV-2 neutralizing antibodies are required. These have been available from NIBSC since December $2020^{16}$. To perform the PRNT and MNA assays, implementers will need an appropriate wild-type SARS-CoV-2 strain or isolate and an operational Advisory Committee on Dangerous Pathogens containment level 3 laboratory (BSL3). To perform the PNA, implementers will need to obtain stocks of the pseudotyped virus or have the necessary expertise to generate these stocks.

For all procedures described here, experience in working with cell culture would be a distinct advantage. For all manipulations involving wild-type SARS-CoV-2 in the PRNT and MNA, operators must be competent in performing standard virological techniques at BSL3. For the PNA, implementers would need the molecular biological expertise to generate the pseudotyped virus stocks if they cannot obtain them commercially.

\section{Materials}

\section{Biological materials}

- Serum samples (either from clinical trial participants or patients for testing) ! CAUTION Appropriate national laws and institutional regulatory board ethical guidelines must be followed and informed consent obtained from patients for the use of human or animal serum in these protocols.

-Wild-type SARS-CoV-2 virus (Victoria/1/2020), supplied to us by the Docherty Institute, then grown and stored at $<-60{ }^{\circ} \mathrm{C}$ in single-use aliquots $\triangle$ CRITICAL In our laboratory, a typical virus stock at $\sim 1 \times 10^{7} \mathrm{pfu} / \mathrm{ml}$ is typically sufficient to set up 50 96-well plates, which would facilitate the testing of $\sim 300$ samples.

- Vero E6 cells (ECACC, cat. no. 85020206) 


\section{Box 2 | Production of wild-type virus stocks for PRNT and MNA $\bigcirc$ Timing 5 d}

\section{Additional reagents and equipment required}

- $5 \mathrm{~mm}$ borosilicate glass beads (sterilized by autoclaving) (Z143944, cat. no. Sigma)

- Vero/hSLAM cells (ECACC, cat. no. 04091501)

$\Delta$ CRITICAL At the Docherty Institute, the virus (Victoria/1/2020) was isolated and grown in Vero/hSLAM cells. In our initial experiments, we found Vero E6 cells to be less satisfactory for growth (Vero E6 produce lower virus titers and are more likely to cause the furin-deletion mutation).

- Geneticin solution, $50 \mathrm{mg} / \mathrm{ml}$ stock (Gibco, cat. no. 10131035)

\section{Additional reagent setup required}

- Vero/hSLAM maintenance medium (10\% FCS): prepare as for PRNT/MNA maintenance medium described in 'Reagent setup' but with the addition of $0.4 \mu \mathrm{g} / \mathrm{ml}$ of Geneticin

- Vero/hSLAM infection medium (0\% FCS): prepare as for Vero/hSLAM maintenance medium but omit the addition of fetal calf serum

- Virus cultivation medium (4\% FCS): prepare as for Vero/hSLAM maintenance media but add $20 \mathrm{ml}$ of fetal calf serum instead of $50 \mathrm{ml}$ to give a final serum concentration of $4 \%$ (vol/vol) FCS.

\section{Procedure}

1 Day 0: seed Vero/hSLAM cells into sufficient T175 flask for desired batch size plus three additional T25 flasks. Seed flasks with $6.0 \times 10^{4}$ cells/ $\mathrm{cm}^{2}$ in Vero/hSLAM maintenance medium and incubate at $37^{\circ} \mathrm{C}$.

2 Day 1: using a microscope, check the cells are $>90 \%$ confluent (i.e., cells are covering at least $90 \%$ of the surface area of the flask area). If they are not, leave the flasks for a further 4-6 $\mathrm{h}$ and repeat the check.

3 Take one of the T25 flasks, remove the medium with a pipette and wash the cell monolayer twice with $5 \mathrm{ml} /$ wash of PBS.

4 Add $1 \mathrm{ml}$ of trypsin-EDTA solution, and place the flask back into the incubator at $37^{\circ} \mathrm{C}$ for $\sim 10$ min until the cells begin to visibly detach.

5 Tap the flask firmly to detach the remaining cells, add $1 \mathrm{ml}$ of Vero/hSLAM maintenance medium and thoroughly resuspend the cells. ! CAUTION It is important that the maintenance medium is added once the cells are detached from the flask to inactivate the trypsin.

6 Mix $100 \mu$ l of the cells with $900 \mu$ l of trypan blue, apply $10 \mu$ lo a counting chamber and count the cells. Calculate the number of cells per $\mathrm{cm}^{2}$ of flask area, and use this figure when calculating the multiplicity of infection (MOI).

7 Remove the medium from the remaining flasks, and wash them twice with $10 \mathrm{ml} /$ wash of PBS. To each T175 flask, add $3.5 \mathrm{ml}$ of infection medium. Add $0.5 \mathrm{ml}$ to one of the T25 flasks (labeled 'CPE positive control') and $1.0 \mathrm{ml}$ to the other (labeled 'CPE negative control').

8 Inspect the flasks thoroughly to ensure that there are no cracks or damage before taking them to the BSL3 laboratory.

! CAUTION All infectious manipulations from this point on need to be performed in a BSL3 laboratory within a MSCIII or suitable alternative such as a flexible film isolator by trained and competent operators.

9 Calculate the dilution required to the stock virus to achieve an MOI of $\sim 0.0005$ based on the cell count $/ \mathrm{cm}^{2}$ from Step 6 and the titer of the stock virus in plaque-forming units per $\mathrm{ml}(\mathrm{pfu} / \mathrm{ml})$. In the MSCIII, dilute the virus and add it to the flasks according to the calculations. For example, if the TC175 contains $2.0 \times 10^{7}$ cells and the stock virus has a titer of $1.5 \times 10^{7} \mathrm{pfu} / \mathrm{ml}$, then the virus needs to be diluted such that $1.0 \times 10^{4} \mathrm{pfu}\left(2.0 \times 10^{7} \times 0.0005\right)$ are added to the flask. In this example, $0.67 \mu \mathrm{l}\left(1.0 \times 10^{4} / 1.5 \times 10^{7}=0.00067 \mathrm{ml}\right)$ is too small a volume to pipette, so a series of three serial 1/10 dilutions in infection medium would be performed and $670 \mu$ added to each T175 flask. Accordingly, $96 \mu \mathrm{l}(670 \times(25 / 175))$ of the same dilution would be added to the T25 flask containing $0.5 \mathrm{ml}$ of infection medium (positive control). The remaining T25 flask is left as a negative control.

10 Return the flasks to the incubator at $37^{\circ} \mathrm{C}$, and rock the flasks gently every $10-15 \mathrm{~min}$ for $1 \mathrm{~h}$.

11 Take the flasks back into the MSCIII, and add $30 \mathrm{ml}$ of virus cultivation medium to each T175 and $5 \mathrm{ml}$ to each T25. Decontaminate the surfaces of the flasks and return them to the incubator at $37^{\circ} \mathrm{C}$. Monitor the T25 flasks (infected and uninfected) daily by phase-contrast microscopy for the presence of cytopathic effect (CPE).

12 Harvest the virus at $\sim 72 \mathrm{~h}$ postinfection when CPE observations reveal $5-20 \%$ of the cells remain attached to the flask. $\triangle$ CRITICAL STEP It is important to harvest the virus before all the cells become detached because the viability of the virus begins to fall when this happens.

13 Add $\sim 10 \mathrm{ml}$ of sterile glass beads to each $\mathrm{T} 175$, and gently rock to detach the remaining cells. Transfer the cell-virus suspension into centrifuge tubes, ensuring they are properly balanced. Seal the tubes into biological containment buckets, decontaminate and bring out to the room centrifuge.

14 Centrifuge the cell-virus suspensions at $1,500 \mathrm{~g}$ for $10 \mathrm{~min}$ at $10{ }^{\circ} \mathrm{C}$, and return the sealed biosafe buckets to the MSCIII.

15 Pool the clarified supernatants, and dispense into $1 \mathrm{ml}$ volumes into prelabeled cryovials.

! CAUTION Ensure that the cryovials used are of a suitable design for storing $\mathrm{HG} 3$ agents (i.e., are capable of withstanding freezing to $-80{ }^{\circ} \mathrm{C}$ and have an O-ring sealed cap).

16 Decontaminate the cryovials, bring them out of the MSCIII and place into an ultralow freezer at $\leq-60{ }^{\circ} \mathrm{C}$. These cryovials are single-use aliquots of virus for both the PRNT and MNA procedures. The virus is stable for at least 6 months when prepared and stored in this manner.

- Heat-inactivated fetal calf serum (Merck, cat. no. F4135-500ML) $\mathbf{C}$ CRITICAL All fetal calf serum used for cell cultivation, virus propagation and assay performance must be heat-inactivated to ensure that no active complement is present to interfere with these assays.

\section{Reagents}

Reagents required for all assays

- PBS (Severn Biotech, cat. no. 207410, or equivalent)

- Trypan blue solution, 0.4\% (Gibco, cat. no. 15250061)

- L-Glutamine solution, 200 mM (Gibco, cat. no. A2916801) 


\section{Box 3 | Procedure for wild-type virus sighting experiments for PRNT}

\section{Procedure}

$\triangle$ CRITICAL This sighting experiment is only performed when using a new virus stock for the first time.

! CAUTION Steps 3-9 involve the use of live SARS-COV-2 virus and must be performed within a class III safety cabinet within a BSL3 facility by trained and competent operators.

\section{Rough sighting experiment $\bigcirc$ Timing $7 \mathrm{~d}$}

1 Day 0: seed a 24-well tissue culture plate with $3 \times 10^{5}$ Vero E6 cells $/ \mathrm{ml}(500 \mu \mathrm{l} /$ well) in PRNT/MNA maintenance medium.

$\triangle$ CRITICAL STEP Maintain cultures of Vero E6 cells such that they are in logarithmic growth (slightly subconfluent) when they are trypsinized, diluted and seeded into plates. Also ensure that the cells are homogeneous and well suspended.

$\triangle$ CRITICAL STEP To ensure even distribution of the cells, rock the 24-well plates at least five times from front to back and side to side to ensure even distribution of the cells, and do not swirl, which can cause the cells to cluster in the middle of the well.

2 Stack and seal the plates into a lid-lock plastic box containing several layers of paper towel that have been moistened with $~ 100 \mathrm{ml}$ of sterile water (for a $5.5 \mathrm{~L}$ box). Incubate the plates at $37^{\circ} \mathrm{C}$ for a minimum of $20 \mathrm{~h}$ before use in the assay.

3 Day 1: in a class III safety cabinet in a BSL3 laboratory, thaw a single-use vial of virus using hand heat and make up tenfold serial dilutions of the virus stock from $10^{-1}$ to $10^{-5}$

$\triangle$ CRITICAL STEP Check that the cells seeded on day 0 are $\geq 85 \%$ confluent and are forming an even monolayer before starting this step.

4 Follow Steps 14-30 of Procedure 1, but add $100 \mu$ of virus dilution in duplicate to cells in Step 18 rather than virus mixture from a neutralization plate. After plaque counting, do not perform neutralization dose calculation (Step 31); instead, continue from Step 5 below.

5 Calculate the arithmetic mean of plaque counts, and select a dilution with an average between 40 and 100 plaques.

6 Calculate the $\mathrm{pfu} / \mathrm{ml}$ of the virus stock using the following equation:

$$
\mathrm{Pfu} / \mathrm{ml}=\text { no. of plaques } /(\text { Dilution } \times \text { Infection volume }(\mathrm{ml}))
$$

7 To create a working stock of virus for PRNT, thaw a single-use vial of virus using hand heat and dilute to $\sim 2 \times 10^{4} \mathrm{pfu} / \mathrm{ml}$ in PRNT/MNA diluent.

8 Dispense into $1 \mathrm{ml}$ volumes into prelabeled cryovials

! CAUTION Ensure that the cryovials used are of a suitable design for storing $\mathrm{HG} 3$ agents (i.e., are capable of withstanding freezing to $-80{ }^{\circ} \mathrm{C}$ and have an O-ring sealed cap with external thread).

$\triangle$ CRITICAL STEP Ensure that vials of virus are stored in aliquots and frozen in a timely manner (ideally no longer than 90 min from thawing to refreezing) to minimize the drop in virus titers from being held at room temperature for too long.

9 Decontaminate the cryovials, bring them out of the MSCIII and place them into an ultralow freezer at $\leq-60{ }^{\circ} \mathrm{C}$. These cryovials are single-use aliquots for PRNT assays, but will require a further fine-sighting experiment to determine the required working dilution (as described below).

\section{Fine sighting experiment 0 Timing $7 \mathrm{~d}$}

! CAUTION Steps 14-16 involve the use of live SARS-CoV-2 virus and must be performed within a class III safety cabinet within a BSL3 facility by trained and competent operators.

10 Day 0: seed three 24-well tissue culture plates with $3 \times 10^{5}$ Vero E6 cells/ml (500 $\mu \mathrm{l} /$ well) in PRNT/MNA maintenance medium. $\triangle$ CRITICAL STEP Maintain cultures of Vero E6 cells such that they are in logarithmic growth (slightly subconfluent) when they are trypsinized, diluted and seeded into plates. Also, ensure that the cells are homogeneous and well suspended.

$\triangle$ CRITICAL STEP To ensure even distribution of the cells, rock the 24-well plates at least five times from front to back and side to side, and do not swirl, which can cause the cells to cluster in the middle of the well.

11 Stack and seal the plates into a lid-lock plastic box containing several layers of paper towel that have been moistened with $100 \mathrm{ml}$ of sterile water (for a $5.5 \mathrm{~L}$ box). Incubate the plates at $37^{\circ} \mathrm{C}$ for a minimum of $20 \mathrm{~h}$ before use in the assay.

12 Day 1: add $75 \mu \mathrm{l} /$ well PRNT/MNA assay diluent into columns 1-5 and 7-11 of a 96-well V-bottom plate. Into columns 6 and 12 , add 150 $\mu$ l PRNT/MNA assay diluent (negative, NVC); this is the mock neutralization plate.

$\triangle$ CRITICAL STEP Check that the cells seeded on day 0 are $\geq 85 \%$ confluent and are forming an even monolayer before starting this step.

13 Prepare 15 tubes with PRNT/MNA assay diluent according to Extended Data Fig. 5 to make a series of virus dilutions from 1/2 to 1/16.

14 In a class III safety cabinet in a BSL3 laboratory, thaw a single-use vial of virus (as generated in Procedure 3, Stage I) using hand heat and add the appropriate amount of virus stock to each tube, as per Extended Data Fig. 5. Mix well using a vortex mixer.

15 Transfer $75 \mu$ of virus dilution in quadruplicate into the mock neutralization plate, columns 1-5 and 7-11.

16 Stack and seal the plates into a lid-lock plastic box containing several layers of paper towel that have been moistened with $\sim 100 \mathrm{ml}$ of sterile water (for a $5.5 \mathrm{~L}$ box). Incubate the plates at $37^{\circ} \mathrm{C}$ for $1 \mathrm{~h}(1.5 \mathrm{~h}$ max) to allow neutralization to occur.

! CAUTION Ensure that the sealed box is externally decontaminated before removing it from the safety cabinet or flexible film isolator.

17 Follow Steps 14-30 of Procedure 1, but do not perform neutralization dose calculation after plaque counting (Step 31); instead, continue from Step 18 below.

18 Calculate the arithmetic mean of the quadruplicate plaque counts for each dilution. The predicted dilution for the working stock should be the dilution at which $\sim 70$ pfu per well are counted.

$\triangle$ CRITICAL STEP This predicted dilution is the working dilution for the virus stock and this sighting procedure will need to be repeated should a new working stock be produced.

PRNT/MNA-specific reagents

- Minimal Essential Medium (MEM; Gibco, cat. no. 21090-022)

- Dulbecco's PBS (DPBS; Gibco, cat. no. 14190169)

- Trypsin-EDTA, 0.25\% (Gibco, cat. no. 25200056)

- 10× MEM (Gibco, cat. no. 11430030)

- Sodium bicarbonate solution, (Gibco, cat no. 25080094)

- HEPES buffer solution, 1 M (Gibco, cat. no. 15630056) 


\section{Box 4 | Wild-type virus semi-fine sighting and regression for the MNA $\bigcirc$ Timing $5 \mathrm{~d}$}

\section{Procedure}

! CAUTION Steps 4-8 involve the use of live SARS-CoV-2 virus and must be performed within a class III safety cabinet within a BSL3 facility by trained and competent operators.

1 Day 0: seed 96-well tissue culture plates with $2.5 \times 10^{5}$ cells/ml $(100 \mu \mathrm{l} /$ well $)$ in PRNT/MNA maintenance medium.

$\triangle$ CRITICAL STEP Maintain cultures of Vero E6 cells such that they are in logarithmic growth (slightly subconfluent) when they are trypsinized, diluted and seeded into plates. Also ensure that the cells are homogeneous and well suspended.

2 Stack and seal the plates into a lid-lock plastic box containing several layers of paper towel that have been moistened with 100 ml of sterile water (for a $5.5 \mathrm{~L}$ box). Incubate the plates at $37^{\circ} \mathrm{C}$ for a minimum of $20 \mathrm{~h}$ before use in the assay.

3 Day 1: into columns 1-11 of a V-bottom plate, pipette $120 \mu \mathrm{l} /$ well of PRNT/MNA assay diluent. Leave column 12 empty (negative, NVC); this is the virus dilution plate.

$\triangle$ CRITICAL STEP Check that the cells seeded on day 0 are $\geq 85 \%$ confluent and are forming an even monolayer before starting this step.

4 Into columns 1-11 of a second V-bottom plate, pipette $75 \mu \mathrm{l} /$ well of PRNT/MNA assay diluent. Into column 12, pipette $150 \mu \mathrm{l} /$ well of diluent (negative, NVC); this is the mock neutralization plate.

5 In a class III safety cabinet in a BSL3 laboratory, add $60 \mu$ of the virus stock to each well in column 1 of the virus dilution plate.

6 Using a multichannel pipette set to $60 \mu$, perform a threefold dilution series of the virus from column 1 to column 11 , mixing each dilution six to eight times before transferring to the next column.

7 Set the multichannel pipette to $75 \mu \mathrm{l}$, and transfer the contents of the virus dilution plate into the mock neutralization plate (columns 1-11 only; column 12 is the NVC).

8 Place the mock neutralization plate into the sealed, humidified box, decontaminate and incubate for $1 \mathrm{~h}$ at $37^{\circ} \mathrm{C}$.

9 Follow Steps 14-36 of Procedure 2, but do not perform neutralization dose determination after foci counting; instead, continue from Step 10 below

10 Input the foci count data (eight replicates per dilution) against the reciprocal of the dilution (i.e., 3, 9, 27, 81 and so on) into a statistical software package such as MiniTab. Where any of the counts at a dilution are $>450 /$ well, exclude/remove those data before proceeding with the regression analysis.

$11 \log _{10}$-transform both the counts and the dilution factors, and perform a linear regression.

12 Rearrange the equation for the regression to predict the dilution factor required to achieve a virus focus count between 125 and 200 per well. $\triangle$ CRITICAL STEP This predicted dilution is the working dilution for the virus stock used, and this procedure will need to be repeated should a new working stock be produced.

- Nonessential amino acids (NEAA), 100× (Gibco, cat. no. 11140035)

- Antibiotic-antimycotic solution, 100× (Gibco, cat. no. 15240062)

- Medium-viscosity carboxymethylcellulose (CMC; Merck, cat. no. C4888)

- Formalin solution, $40 \%$ (wt/vol) (e.g., Sigma, cat. no. F8775)

\section{PRNT-specific reagents}

- Crystal violet $0.2 \%$ ( $\mathrm{wt} / \mathrm{vol}$ ) in $20 \%$ (vol $/ \mathrm{vol}$ ) ethanol solution, prepared from $1 \%$ stock (Sigma, cat. no. V5265)

\section{MNA-specific reagents}

- Hydrogen peroxide solution 30\% (vol/vol) (Merck, cat. no. H1009)

- Anti-spike rabbit polyclonal antibody (Sino Biologicals, cat. no. 40592-T62) $\triangle$ CRITICAL The MNA assay has been developed and optimized for this primary detection antibody. Other antibodies would require optimization of the immunostaining stage of the procedure.

- Anti-rabbit IgG goat-horseradish peroxidase conjugate (Invitrogen, cat. no. G21234) $\Delta$ CRITICAL The MNA assay has been developed and optimized for this secondary conjugate. Other antibodies would require optimization of the immunostaining stage of the procedure.

- Substrate, TrueBlue (SeraCare KPL, cat. no. 5510-0050) $\Delta$ CRITICAL The MNA assay has been developed and optimized for this substrate. Other substrates would require optimization of the immunostaining stage of the procedure.

\section{PNA-specific reagents}

- Dulbecco's Modified Eagle Medium (DMEM; Gibco, cat. no. 11960-085)

- ONE-GLO EX Luciferase assay system (Promega, cat. no. E8110)

- ESF-SFM medium (Expression Systems, cat. no. 98-001)

- FreeStyle MAX reagent (Thermo Fisher Scientific, cat. no. 16447100)

- Accutase (Gibco, cat. no. A11105-01)

- Opti-Pro SFM medium (Thermo Fisher Scientific, cat. no. 12309050)

- Pseudotyped $\Delta$ G-luciferase (G* $\Delta$ G-luciferase) rVSV (Kerafast, cat. no. EH1020-PM) 


\section{Box 5 | Creation and production of pseudotyped virus for PNA $\bigcirc$ Timing $2 \mathrm{~d}$}

\section{Procedure}

1 Day 0: seed ES-293 cells at $0.8 \times 10^{6}$ cells $/ \mathrm{ml}$ in ESF-SFM medium and incubate in an orbital shaker incubator overnight at $37{ }^{\circ} \mathrm{C} / 5 \% \mathrm{CO}_{2}$.

2 Day 1: dilute $1250 \mu \mathrm{g}$ of plasmid DNA containing the spike $\Delta$ CT from SARS-CoV-2 Wuhan strain into OptiPro SFM to a total of $20 \mathrm{ml}$ and mix gently.

3 In a separate tube, dilute $1250 \mu \mathrm{l}$ of FreeStyle Max transfection reagent in OptiPro SFM to a $20 \mathrm{~mL}$ and mix gently.

$4 \mathrm{Immediately}$ add the diluted plasmid and transfection reagent together to reach a final volume of $40 \mathrm{ml}$. Incubate the mixture for $10 \mathrm{~min}$ at room temperature.

5 Slowly add the DNA/transfection reagent mixture to the cells, and incubate in an orbital shaker $\left(48 \mathrm{~h}\right.$ at $37{ }^{\circ} \mathrm{C} / 5 \% \mathrm{CO}_{2}$ ).

6 Determine the cell concentration and adjust the concentration to $5.0 \times 10^{6} \mathrm{cell} / \mathrm{s} / \mathrm{ml}$.

7 Add the pseudotyped $\Delta \mathrm{G}$-luciferase $\left(\mathrm{G}^{\star} \Delta \mathrm{G}\right.$-luciferase) $\mathrm{rVSV}$ at an $\mathrm{MOI}=3$. Incubate for $2 \mathrm{~h}$ without shaking.

8 Centrifuge at $300 \mathrm{~g}$ for $5 \mathrm{~min}$ at room temperature, and resuspend the pellet in prewarmed ESF-SFM medium.

9 Incubate in an orbital shaker incubator for $24 \mathrm{~h}$ at $37^{\circ} \mathrm{C} / 5 \% \mathrm{CO}_{2}$.

10 Collect the culture and centrifuge at $1,000 \mathrm{~g}$ for $5 \mathrm{~min}$ at room temperature.

11 Transfer the supernatant on a $0.2 \mu \mathrm{m}$ filter funnel.

12 Store at $-80^{\circ} \mathrm{C}$ in $1 \mathrm{~mL}$ aliquot (single-use aliquot).

$\triangle$ CRITICAL STEP For each batch of pseudotyped virus, a titration on Vero E6 cells is performed using an anti-luciferase antibody to enable detection of foci-forming units instead of relative light units (RLUs).

$\triangle$ CRITICAL STEP A neutralization assay with and without anti-VSV antibody is used to demonstrate the absence of any residual nonpseudotyped $\Delta \mathrm{G}$-luciferase $\left(\mathrm{G}^{\star} \Delta \mathrm{G}\right.$-luciferase) rVSV. If there is no residual nonpseudotyped virus, both titration curves (with and without anti-VSV antibody) will overlap.

- pSF-CMV-Amp CMV promoter plasmid (Sigma, cat. no. OGS2) containing the SARS-CoV-2 spike $\Delta \mathrm{CT}$ encoding gene $(\Delta \mathrm{CT}=$ deletion the last 19 amino acids of the spike glycoprotein, corresponds to the cytoplasmic tail); the plasmid will need to be generated (not available from the authors or deposited in a bank)

-293-ES cells (Expression Systems, cat. no. 94-007F)

\section{Equipment}

Equipment required for all assays

- Sterile 96-well, low-absorption, V-bottomed lidded plates (Thermo Fisher Scientific, cat. no. 249935)

- Sterile vent/close T175 and T25 cell culture flasks (Thermo Fisher Scientific, cat. nos. 159920 and 156340)

- Disposable counting chamber, C-chip (NanoEntek, cat. no. DHC-N01)

- Laboratory single and multichannel pipettes (e.g., Rainin LTS, cat. nos. L-1000XLS+, L-200XLS+, L-20XLS+ and L12-300XLS+)

- Class II microbiological safety cabinet (e.g., Contained Air Solutions, cat. no. BioMAT 2)

- Laboratory incubators capable of $37{ }^{\circ} \mathrm{C}$ (with additional $\mathrm{CO}_{2}$ control for PNA; e.g., Eppendorf, cat. no. 6734000012)

- Laboratory refrigerator $\left(2-8{ }^{\circ} \mathrm{C}\right.$; e.g., Fisher Scientific, cat. no. 11317941$)$ and freezer $\left(-15\right.$ to $-30{ }^{\circ} \mathrm{C}$; e.g., Fisher Scientific, cat. no. 15588229)

- Laboratory ultralow freezer $\left(\leq-60{ }^{\circ} \mathrm{C}\right.$; e.g., Fisher Scientific, cat. no. 15830620)

- Orbital 96-well plate shakers (e.g., VWR, cat. no. 444-9143 with rack system VWR, cat. no. 444-0519)

- Inverted phase-contrast microscope (e.g., Leica microsystems, cat. no. 11526216, with accessories, cat. nos. 13613532, 11526118, 11526111, 11506271, 11506272)

- Microcentrifuge (e.g., Thermo Fisher Scientific, cat. no. 75002410)

- 96-well plate washer with cell-based assay capability (BioTek, cat. no. 405 TSUS)

- SoftMax Pro Software version 7.0.3 or greater (Molecular Devices, cat. no. SMP7X GXP SINGLE COMP or SMP7X GXP SERVER)

- Laboratory water bath (e.g. Fisher Scientific, cat. no. 12718898)

\section{PRNT/MNA-specific equipment}

- Class III microbiological safety cabinet (MSCIII) or suitable equivalent (e.g., flexible film isolator) (e.g., Contained Air Solutions, built to order; contact supplier directly)

- Plastic boxes with airtight, leakproof, four-sided lockable lid (LocnLock 5.5 L, cat. no. HPL836)

- ImmunoSpot S6 Ultra-V analyser with BioSpot counting module (Cellular Technologies Europe, contact supplier directly) (only required for MNA)

- Sterile 96-well, tissue culture treated, flat-bottomed lidded plates (Thermo Fisher Scientific, cat. no. 161093) (only required for MNA) 


\section{Box 6 | Pseudotyped virus dose sighting Timing $2 \mathrm{~d}$}

\section{Procedure}

$\triangle$ CRITICAL This stage is performed on each new lot of pseudotyped virus to determine the amount of SARS-CoV-2 pseudotyped virus particles to be used during the PNA.

1 Day 0: seed 96-well plates with $2.0 \times 10^{5}$ cells $/ \mathrm{ml}(100 \mu \mathrm{l} /$ well $)$ of Vero E6 cells in PNA maintenance medium, and incubate overnight at $37^{\circ} \mathrm{C} / 5 \% \mathrm{CO}_{2}$.

2 Day 1: ensure that the cells seeded on day 0 are $>80 \%$ confluent.

3 Perform a double-dilution series of the pseudotyped virus in duplicate, and assess in the PNA without the addition of neutralizing serum-in effect, performing a mock assay by following Steps 8-14 of Procedure 3.

4 Perform a linear regression of mean RLUs against fold dilution of virus for the two dilutions flanking the 150,000 RLUs.

5 Interpolate from the regression the dilution required to achieve 150,000 RLUs.

$\triangle$ CRITICAL STEP Based on the titer of the batch, the dilution to be used for the PNA is adjusted such that a target of 150,000 RLUs/well is used. The standardized pseudotyped virus input makes the PNA stable and robust over time.

PNA-specific equipment

- SpectraMax i3x plate reader (Molecular Device, contact supplier directly)

- Vacuum pump system (e.g., Fisher Scientific, cat. no. 12911151)

- $0.22 \mu \mathrm{m}$ filtration unit (Sigma, cat. no. SCGPU05RE)

- Sterile 96-well, polypropylene, U-bottomed lidded plates (Thermo Fisher Scientific, cat. no. 267334/264623)

- Sterile 96-well flat-bottom white plates (Corning, cat. no. 3917)

\section{Reagent setup \\ PRNT/MNA-specific reagent setup \\ PRNT/MNA maintenance medium (10\% FCS)}

To one $500 \mathrm{ml}$ bottle of MEM, add $5 \mathrm{ml}$ of L-glutamine, $5 \mathrm{ml}$ of nonessential amino acids, $13 \mathrm{ml}$ of HEPES buffer (1M) and $50 \mathrm{ml}$ of heat-inactivated FCS. Can be aseptically made in advance and stored at $2-8{ }^{\circ} \mathrm{C}$ for up to 2 months.

PRNT/MNA assay diluent (1\% FCS)

To one $500 \mathrm{ml}$ bottle of MEM, add $5 \mathrm{ml}$ of L-glutamine, $5 \mathrm{ml}$ of nonessential amino acids, $13 \mathrm{ml}$ of HEPES buffer (1M), $5 \mathrm{ml}$ of heat-inactivated FCS and $5 \mathrm{ml}$ of $100 \times$ antibiotic-antimycotic solution. Can be aseptically made in advance and stored at $2-8{ }^{\circ} \mathrm{C}$ for up to 2 months.

\section{PRNT/MNA overlay medium}

Prepare 2\% (for MNA) or 3\% (for PRNT) (wt/vol) CMC solution in water and sterilize by autoclaving. Can be aseptically made in advance and stored at ambient temperature for up to 2 months. $\triangle$ CRITICAL CMC forms clumps easily when attempting to dissolve it in water. To successfully make this reagent, heat the water to $\sim 50{ }^{\circ} \mathrm{C}$ in a microwave and add the $\mathrm{CMC}$ powder very gradually with regular shaking.

In a class II safety cabinet, aseptically prepare double-strength medium by mixing $142 \mathrm{ml}$ of sterile bottled water with $50 \mathrm{ml}$ of $10 \times$ MEM, $15 \mathrm{ml}$ of $7.5 \%$ (wt/vol) sodium bicarbonate solution, $5 \mathrm{ml}$ of L-glutamine solution, $5 \mathrm{ml}$ of nonessential amino acids, $13 \mathrm{ml}$ of $1 \mathrm{M}$ HEPES and $20 \mathrm{ml}$ of FCS. Can be made aseptically in advance and stored at $2-8{ }^{\circ} \mathrm{C}$ for up to 2 months.

On the day of the assay, mix the CMC solution/paste 1:1 with the double-strength medium, add antibiotic-antimycotic solution to a final concentration of $1 \times$ and mix thoroughly by shaking. Warm to $37^{\circ} \mathrm{C}$ after preparation, and use within $10 \mathrm{~h}$.

\section{PRNT/MNA fixative}

Add $200 \mathrm{ml}$ formalin (40\% (wt/vol) formaldehyde solution) to $800 \mathrm{ml}$ of PBS. ! CAUTION Formalin is a hazardous chemical, and this procedure must be performed in a fume hood or other safety cabinet ducted to atmosphere; wear protective gloves when handling formalin and the prepared fixative.

\section{PNA-specific reagent setup}

\section{PNA maintenance medium/assay diluent}

To one $1,000 \mathrm{ml}$ bottle of DMEM, add $10.9 \mathrm{ml}$ of L-glutamine, $10.9 \mathrm{ml}$ sodium pyruvate, $10.9 \mathrm{ml}$ of MEM nonessential amino acids and $54.5 \mathrm{ml}$ of heat-inactivated FCS. Can be aseptically made in advance and stored at $2-8{ }^{\circ} \mathrm{C}$ for up to 1 month. 


\section{Procedure}

\section{Procedure 1: PRNT $\bigcirc$ Timing 1 week}

$\triangle$ CRITICAL Before starting this assay, it is essential to inactivate components of the complement system by following the sample-preparation procedure in Box 1. Virus stock solutions must also be prepared in advance by following the procedure in Box 2. When using a new virus stock for the first time, wild-type virus rough and fine sighting experiments must be performed (Box 3).

$\triangle$ CRITICAL All steps in this procedure must be performed aseptically in a class II or class III (where indicated) safety cabinet to ensure the sterility of the assay.

\section{Stage I: serum dilution Timing 1-2 h}

1 Day 0: seed 24-well tissue culture plates with $3 \times 10^{5}$ Vero E6 cells/ml (500 $\mu \mathrm{l} /$ well) in PRNT/MNA maintenance medium.

$\triangle$ CRITICAL STEP Maintain cultures of Vero E6 cells such that they are in logarithmic growth (slightly subconfluent) when they are trypsinized, diluted and seeded into plates. Also ensure that the cells are homogeneous and well suspended.

$\triangle$ CRITICAL STEP To ensure even distribution of the cells, rock the 24-well plates at least five times from front to back and side to side to ensure even distribution of the cells, and do not swirl, which can cause the cells to cluster in the middle of the well.

2 Stack and seal the plates into a lid-lock plastic box containing several layers of paper towel that have been moistened with $\sim 100 \mathrm{ml}$ of sterile water (for a $5.5 \mathrm{~L} \mathrm{box}$ ). Incubate the plates at $37^{\circ} \mathrm{C}$ for a minimum of $20 \mathrm{~h}$ before use in the assay.

3 Day 1: remove heat-inactivated serum from the freezer, and thaw at ambient temperature. Record any unusual observations of the test samples, e.g., hemolysis or lipemia. These observations can be added to the report along with $\mathrm{ND}_{50}$ measurements.

$\triangle$ CRITICAL STEP Check that the cells seeded on day 0 are $\geq 85 \%$ confluent and are forming an even monolayer before starting this step.

4 Dispense PRNT/MNA assay diluent into a 96-well V-bottom plate as follows: into wells $\mathrm{C} 1$ to $\mathrm{H1}$ and A7 to H7, dispense $135 \mu \mathrm{l} /$ well; into wells A6 and B6, dispense $150 \mu \mathrm{l}$; and into all other wells, dispense $75 \mu$ l. The layout of each 96-well plate (Fig. 2a) corresponds to four 24-well plates (Fig. $2 \mathrm{~b}$ for the control wells, and three of Fig. 2c for the samples).

$\triangle$ CRITICAL STEP It is not recommended to exceed two 96-well plates, as more than this can affect the VOC reaching acceptability criteria owing to the additional manipulation times. However, only one control plate per assay is required (i.e., a maximum of 14 samples per control plates).

5 Predilute any serum in PRNT/MNA assay diluent that has already been determined to have a neutralizing titer of greater than $1 / 640$. The reference serum is also likely to need predilution to ensure that the 50\% neutralization dose falls within the range of the assay, depending upon the source.

$\triangle$ CRITICAL STEP The first dilution into the plate always gives a $1 / 20$ final dilution, so this must be borne in mind when performing any predilution; e.g., if a dilution series starting at $1 / 640$ is required, perform a predilution of 1/32 (given the additional 1/20 performed in Step 6, the first dilution will be $1 / 640$ ).

6 To the first two wells of each sample position (i.e., for sample 1, wells E1 and F1), pipette $15 \mu \mathrm{l} /$ well of the sample serum (prediluted serum).

$\triangle$ CRITICAL STEP This dilution is a $1 / 10$ of serum in medium, but later in the procedure (prior to neutralization), an equal volume of virus is added to each well, doubling this initial dilution to $1 / 20$.

7 Continue to add test serum to the remaining positions on the plate.

8 Add the (prediluted) reference serum to wells $\mathrm{C} 1$ and D1.

9 With a multichannel pipette set to $75 \mu \mathrm{l}$, double-dilute the serum (six to eight mixes at each column) across the plate, discarding the final $75 \mu \mathrm{l}$ at the end of each row.

$\triangle$ CRITICAL STEP At the end of this step, all wells should contain $75 \mu$ except for the two no-virus control (NVC) wells A6 and B6, which should contain $150 \mu$ l.

10 Take the diluted serum in the neutralization plates to the containment level 3 laboratory.

Stage II: virus addition and neutralization Timing $1.5 \mathrm{~h}$

! CAUTION Stages II to V involve the use of live SARS-CoV-2 virus and must be performed within a class III safety cabinet within a BSL3 facility by trained and competent operators. 


\begin{tabular}{|c|c|c|c|c|c|c|c|c|c|c|c|c|}
\hline & 1 & 2 & 3 & 4 & 5 & 6 & 7 & 8 & 9 & 10 & 11 & 12 \\
\hline B & \multicolumn{5}{|c|}{ Virus-only control (VOC) } & $\begin{array}{c}\text { No } \\
\text { virus } \\
\text { control } \\
\text { (NVC) }\end{array}$ & $\begin{array}{c}\text { S3 } \\
1: 20\end{array}$ & $\begin{array}{c}\text { S3 } \\
1: 40\end{array}$ & $\begin{array}{c}\text { S3 } \\
1: 80\end{array}$ & $\begin{array}{c}\text { S3 } \\
1: 160\end{array}$ & $\begin{array}{c}\text { S3 } \\
1: 320\end{array}$ & $\begin{array}{c}\text { S3 } \\
1: 640\end{array}$ \\
\hline D & $\begin{array}{c}R 1 \\
1: 20\end{array}$ & $\begin{array}{c}R 1 \\
1: 40\end{array}$ & $\begin{array}{c}R 1 \\
1: 80\end{array}$ & $\begin{array}{c}\text { R1 } \\
1: 160\end{array}$ & $\begin{array}{c}\text { R1 } \\
1: 320\end{array}$ & $\begin{array}{c}\text { R1 } \\
1: 640\end{array}$ & $\begin{array}{c}\text { S4 } \\
1: 20\end{array}$ & $\begin{array}{c}\text { S4 } \\
1: 40\end{array}$ & $\begin{array}{c}\text { S4 } \\
1: 80\end{array}$ & $\begin{array}{c}\text { S4 } \\
1: 160\end{array}$ & $\begin{array}{c}\text { S4 } \\
1: 320\end{array}$ & $\begin{array}{c}\text { S4 } \\
1: 640\end{array}$ \\
\hline $\mathrm{F}$ & $\begin{array}{c}\text { S1 } \\
1: 20\end{array}$ & $\begin{array}{c}\text { S1 } \\
1: 40\end{array}$ & $\begin{array}{c}\text { S1 } \\
1: 80\end{array}$ & $\begin{array}{c}\text { S1 } \\
1: 160\end{array}$ & $\begin{array}{c}S 1 \\
1: 320\end{array}$ & $\begin{array}{c}\text { S1 } \\
1: 640\end{array}$ & $\begin{array}{c}\text { S5 } \\
1: 20\end{array}$ & $\begin{array}{c}\text { S5 } \\
1: 40\end{array}$ & $\begin{array}{c}\text { S5 } \\
1: 80\end{array}$ & $\begin{array}{c}\text { S5 } \\
1: 160\end{array}$ & $\begin{array}{c}\text { S5 } \\
1: 320\end{array}$ & $\begin{array}{c}\text { S5 } \\
1: 640\end{array}$ \\
\hline $\mathrm{H}$ & $\begin{array}{c}\text { S2 } \\
1: 20\end{array}$ & $\begin{array}{c}\text { S2 } \\
1: 40\end{array}$ & $\begin{array}{c}\text { S2 } \\
1: 80\end{array}$ & $\begin{array}{c}\text { S2 } \\
1: 160\end{array}$ & $\begin{array}{c}\text { S2 } \\
1: 320\end{array}$ & $\begin{array}{c}\text { S2 } \\
1: 640\end{array}$ & $\begin{array}{c}\text { S6 } \\
1: 20\end{array}$ & $\begin{array}{c}\text { S6 } \\
1: 40\end{array}$ & $\begin{array}{c}\text { S6 } \\
1: 80\end{array}$ & $\begin{array}{c}\text { S6 } \\
1: 160\end{array}$ & $\begin{array}{c}S 6 \\
1: 320\end{array}$ & $\begin{array}{c}\text { S6 } \\
1: 640\end{array}$ \\
\hline
\end{tabular}

b

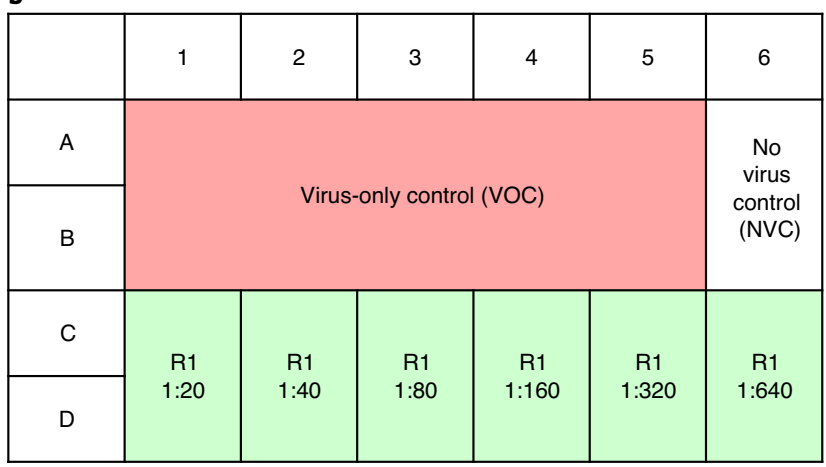

C

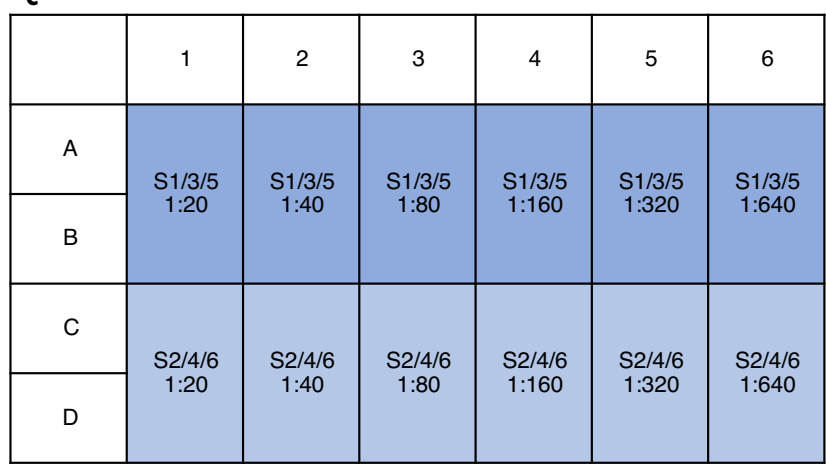

Fig. 2 | Typical plate layout of the PRNT. a, Due to the plaque assay element of the assay, each 96-well neutralization plate requires four 24-well cell plates. b. The first 24-well cell plate contains the VOC and reference wells. c, The remaining three 24 -well cell plates contain samples 1 to 6 . VOC contains no serum and is used to determine the foci count (100\% unneutralized) for the analysis. NVC contains no serum or virus and is used to ensure that cell monolayers are of good quality and that no virus cross-contamination has occurred during assay setup.

11 Thaw a single-use vial of virus using hand heat, and dilute it to the working dilution determined previously (Box 3). Dilute the virus in PRNT/MNA assay; allow for a volume of $9 \mathrm{ml}$ of diluted virus per plate.

12 Using a multichannel pipette, add $75 \mu \mathrm{l} /$ well of the diluted virus to each well of the $\mathrm{V}$-well neutralization plate except for the NVC wells (A6 and B6).

13 Stack and seal the plates into a lid-lock plastic box containing several layers of paper towel that have been moistened with $\sim 100 \mathrm{ml}$ of sterile water (for a $5.5 \mathrm{~L}$ box). Incubate the plates at $37^{\circ} \mathrm{C}$ for $1 \mathrm{~h}$ (1.5 $\mathrm{h}$ max) to allow neutralization to occur.

! CAUTION Ensure that the sealed box is externally decontaminated before removing it from the safety cabinet or flexible film isolator.

Stage III: virus adsorption Timing $1.5 \mathrm{~h}$

14 In the cell culture laboratory, take the 24-well plate containing the Vero E6 cells into a class II safety cabinet. Using the cell-capable plate washer, run a cell wash program, which should remove $250 \mu \mathrm{l}$ of the maintenance medium from the cells. Then perform two $500 \mu \mathrm{l}$ washes with DPBS, leaving the second wash in the wells.

$\triangle$ CRITICAL STEP To prevent the cells from drying out during the assay, a residual volume of $\sim 250 \mu \mathrm{l}$ is always left on the cells. At the end of this step, the wells of the cell plate each contain $\sim 750 \mu \mathrm{l}$ of DPBS.

15 Transfer the washed cell plates to the containment level 3 laboratory, label them to match the numbering used on the neutralization plates and place them in the safety cabinet.

16 Take the box containing the neutralization plates back into the safety cabinet.

17 Using a stripette, remove $\sim 500 \mu \mathrm{l}$ of DPBS from all wells of the cell plate.

$\triangle$ CRITICAL STEP To avoid the risk of cell monolayers drying out in the high airflow of the class III safety cabinet, perform Steps 17 and 18 one plate at a time. 
18 Transfer $100 \mu \mathrm{l}$ of the neutralized virus-antibody mixture from the neutralization plate into the cell plate. This is best performed one row at a time, working from left to right (i.e., strongest serum dilution to weakest, which equates to fewest plaques to most plaques) and changing tips after each row to avoid sample-to-sample contamination.

19 Rock the plates at least five times from front to back and side to side.

$\triangle$ CRITICAL STEP To ensure even distribution of the virus, rock the 24 -well plate, and do not swirl, which can cause the virus to cluster in the middle of the well.

20 Stack and seal the plates into a lid-lock plastic box containing several layers of paper towel that have been moistened with $\sim 100 \mathrm{ml}$ of sterile water (for a $5.5 \mathrm{~L}$ box). Incubate the plates at $37^{\circ} \mathrm{C}$ for $1 \mathrm{~h}$ (1.5 h max) to allow adsorption to occur.

! CAUTION Ensure that the sealed box is externally decontaminated before removing it from the safety cabinet or flexible film isolator.

Stage IV: addition of overlay medium and incubation Timing $25 \mathrm{~min}$ to $\mathbf{1 ~ h}$

21 Take the box containing the adsorption plates back into the safety cabinet.

22 Without removing the inoculum, gently add $500 \mu \mathrm{l}$ of warmed overlay medium to each well of the plate. This is best performed using a stripette owing to the high viscosity of the overlay medium.

23 Stack and seal the plates into a lid-lock plastic box containing several layers of paper towel that have been moistened with $\sim 100 \mathrm{ml}$ of sterile water (for a $5.5 \mathrm{~L}$ box). Incubate the plates at $37{ }^{\circ} \mathrm{C}$ for $5 \mathrm{~d}$ to allow plaques to form.

! CAUTION Ensure that the sealed box is externally decontaminated before removing it from the safety cabinet or flexible film isolator.

Stage V: fixing and inactivation of virus Timing $\sim 12 \mathrm{~h}$

24 Take the boxes containing the plates into the MSCIII, and add $500 \mu \mathrm{l}$ of PRNT/MNA fixative to each well of the assay plates.

25 Fumigate the MSCIII overnight with formaldehyde vapor, or make the plates safe for transferring out of the containment level 3 laboratory according to local safety protocols.

$\triangle$ CRITICAL STEP The addition of formalin to the wells inactivates the SARS-CoV-2 virus as well as chemically fixing the cell monolayers. Fumigation should ensure that no residual virus on lids or between wells remains viable. This critical step is an important safety check because, from this point on, the plates are considered noninfectious.

! CAUTION To ensure a good seal of the box, it is good practice to lightly grease the rubber or silicone lid gasket with silicone/vacuum grease after each use.

Stage VI: staining, counting and scoring of plaque counts Timing $\sim 1 \mathbf{d}$

26 Remove fixed medium from all wells, and collect into a formaldehyde waste receptacle before removing from the MSCIII.

! CAUTION Formaldehyde is a dangerous chemical. Inactivate waste formaldehyde according to local protocols before disposal.

27 Wash plates by submerging in copious amounts of tap water to remove traces of formaldehyde.

28 Add $0.2 \%$ (wt/vol) crystal violet stain to all wells. The volume is not critical but must be sufficient to cover the monolayer $(\sim 250 \mu \mathrm{l})$. Stain for 5-15 min following addition to the last well.

29 Aspirate or pour off the crystal violet solution, and wash plates twice with copious amounts of tap water.

! CAUTION Crystal violet solution is toxic to the aquatic environment, so waste must be collected and disposed of according to local protocols.

30 Tap plates on absorbent material to remove excess liquid, and allow to air dry before counting.

31 Manually count plaques using a white light box. Use a nonpermanent marker to place a single dot on recognized plaques to prevent double-counting. Record the counts on the plate next to each well. Do not use a microscope, and count only macroscopically visible plaques. If multiple plaques are close together but can be clearly distinguished, these can be counted as separate plaques. If a large plaque does not have internal borders (suggesting multiple plaques growing closely together), this should be counted as a single plaque.

32 Collate the counts into a spreadsheet for analysis.

33 Ask a second trained operator to check the spreadsheet against information originally recorded on the assay plates to ensure that all the data have been correctly captured. 


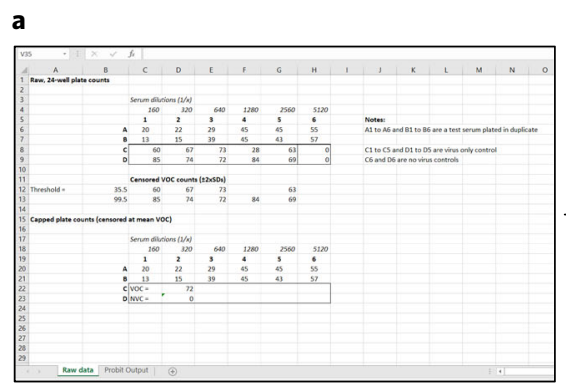

b
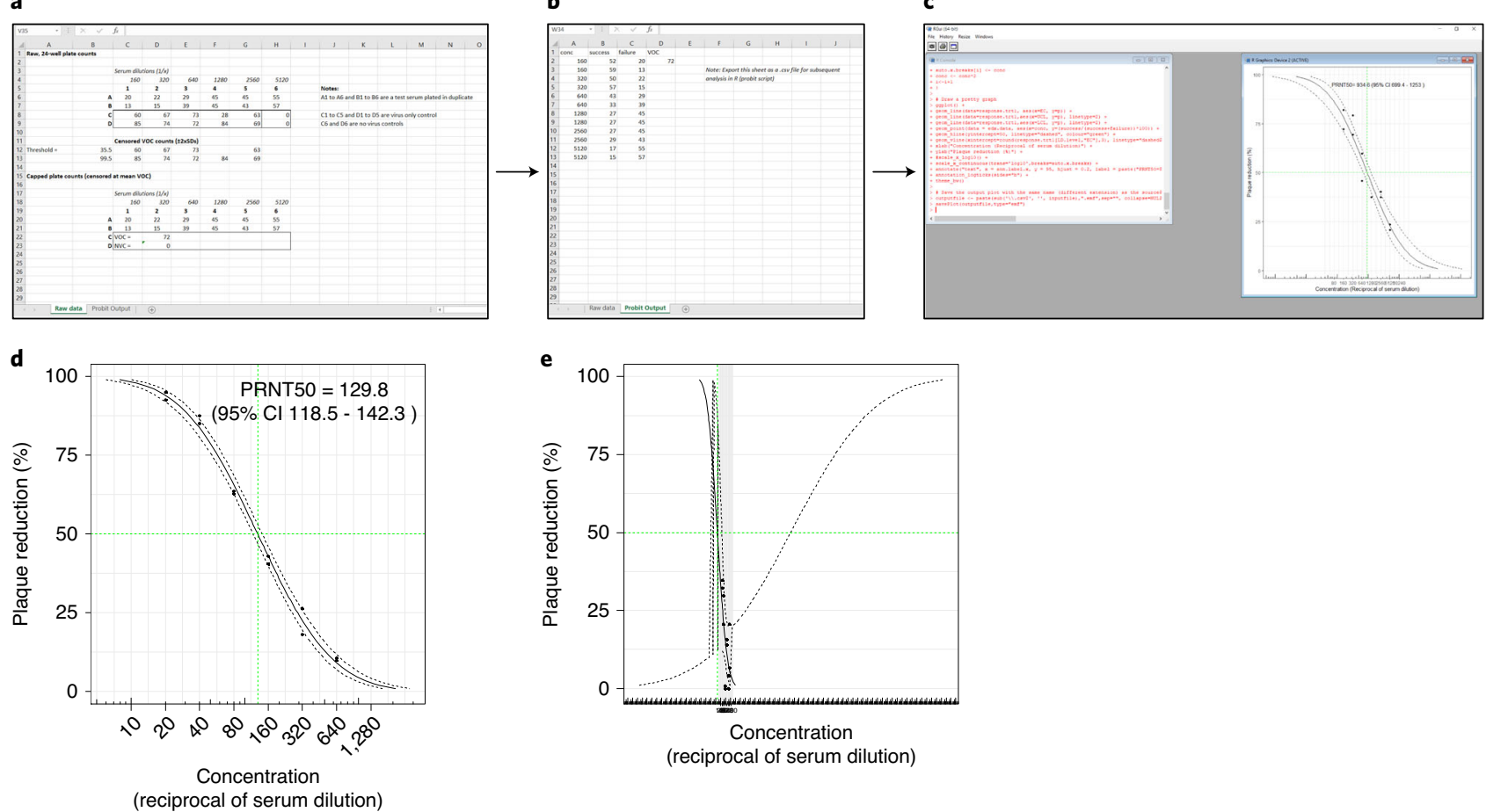

e

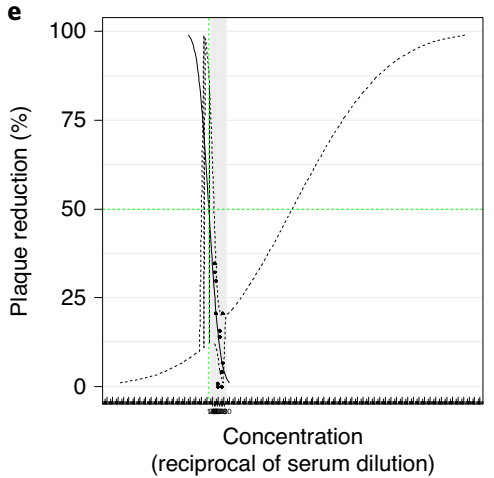

Fig. 3 | Protocol for calculating the ND $_{50}$ for serum by PRNT assay using Probit analysis in R. a, Plaque counts should be limited to the average of the VOC counts. b, Counts should be arranged in a new worksheet, as shown, and saved as a .csv file. c, Following analysis using the R script supplied, a graph is generated and automatically saved as an .EMF file. d, An example of a good result with a full curve and tight confidence intervals. e, An example of a graph generated for a nonneutralizing sample with a poor curve.

34 In Microsoft Excel, generate a new spreadsheet and limit the plaque counts to the average of the VOC counts (Fig. 3a).

35 In a new sheet within Microsoft Excel, generate four column headers, starting in cell A1, labeled as conc, success, failure and VOC. In the 'conc' column, input the reciprocal of the dilutions used for the sample being analyzed (e.g., 20, 40, 80, 160, 320, 640). In the 'failure' column, input the capped plaque counts for one sample alongside the corresponding dilution. In the 'VOC' column, add the average VOC count. To calculate the 'success' rate, subtract the plaque count (failure) from the VOC (Fig. 3b).

36 Save this worksheet as a .csv file with the sample ID.

37 Open the freely available software package ' $R$ ', and paste in the code supplied in the supplementary files (Supplementary Software 1). When prompted, select the .csv file to be analyzed. $\mathrm{R}$ will then generate a graph with the appropriate scale and calculate the median neutralizing dose $\left(\mathrm{ND}_{50}\right)$ with confidence intervals. The graph will be automatically saved as an .EMF file in the original folder with the same name (Fig. $3 c-e$ ).

38 Check that the data fulfill the requirements of the PRNT assay suitability criteria presented in Table 1.

\section{Procedure 2: microneutralization assay (MNA) Timing $3 \mathrm{~d}$}

$\triangle$ CRITICAL Before starting this assay, it is essential to inactivate components of the complement system by following the sample-preparation procedure in Box 1. Virus stock solutions must also be prepared in advance by following the procedure in Box 2. When using a new virus stock for the first time, wild-type virus semifine sighting experiments must be performed (Box 4).

$\triangle$ CRITICAL All steps in this procedure must be performed aseptically in a class II or class III (where indicated) safety cabinet to ensure the sterility of the assay.

Stage I: serum dilution Timing $1-2.5 \mathbf{h}$

1 Day 0: seed 96-well tissue culture plates with $2.5 \times 10^{5}$ cells/ml (100 $\mu \mathrm{l} /$ well) in PRNT/MNA maintenance medium. 
Table 1 | System suitability criteria (criteria 1-3) and test sample criteria (criteria 4-9) for the PRNT

\begin{tabular}{|c|c|}
\hline Criterion & Description \\
\hline 1 & The negative control wells should have no plaques \\
\hline 2 & $\begin{array}{l}\text { No more than one well on the control plate should have a monolayer disturbed by nonspecific } \\
\text { means, e.g., mechanical damage greater than five plaques or cells sloughing off }\end{array}$ \\
\hline 3 & $\begin{array}{l}\text { The mean plaque count of the VOC should give a plaque count ranging from } 60 \text { to } 110 \text { mean pfu/ } \\
\text { well }\end{array}$ \\
\hline 4 & $\begin{array}{l}\text { None of the test sample wells should have a monolayer disturbed by nonspecific means, e.g., } \\
\text { mechanical damage greater than five plaques or cells sloughing off }\end{array}$ \\
\hline 5 & Plaques should not be too numerous to count in any well \\
\hline 6 & In wells with $<5$ pfu, the duplicate counts for that test sample dilution should be $<10$ \\
\hline 7 & $\begin{array}{l}\text { In wells with } \geq 5 \text { pfu, the duplicate counts for each test sample dilution should not be more than } \\
\text { twofold different from each other }\end{array}$ \\
\hline 8 & $\begin{array}{l}\text { If the mean pfu/well at any dilution is }<80 \% \text { of VOC, the mean pfu/well at greatest dilution should } \\
\text { be greater than mean pfu/well at least dilution of test sample }\end{array}$ \\
\hline 9 & $\begin{array}{l}\text { Mean pfu/well should not be between } 50-80 \% \text { of mean VOC at any dilution of test sample (i.e., } \\
\text { response curve does not cross } 50 \% \text { neutralization) }\end{array}$ \\
\hline
\end{tabular}

$\triangle$ CRITICAL STEP Maintain cultures of Vero E6 cells such that they are in logarithmic growth (slightly subconfluent) when they are trypsinized, diluted and seeded into plates. Also ensure that the cells are homogeneous and well suspended.

2 Stack and seal the plates into a lid-lock plastic box containing several layers of paper towel that have been moistened with $\sim 100 \mathrm{ml}$ of sterile water (for a $5.5 \mathrm{~L}$ box). Incubate the plates at $37{ }^{\circ} \mathrm{C}$ for a minimum of $20 \mathrm{~h}$ before use in the assay.

3 Day 1: remove heat-inactivated serum from the freezer, and thaw at ambient temperature, recording any unusual observations of the test samples, e.g., hemolysis or lipemia. These observations can be added to the report along with $\mathrm{ND}_{50}$ measurements.

$\triangle$ CRITICAL STEP Check that the cells seeded on day 0 are $\geq 85 \%$ confluent and are forming an even monolayer before starting this step.

4 Dispense PRNT/MNA assay diluent into a 96-well V-bottom plate as follows: into wells A1 to H1 and A7 to F7, dispense $135 \mu \mathrm{l} /$ well; into wells G12 and H12, dispense $150 \mu \mathrm{l}$; and into all other wells, dispense $75 \mu \mathrm{l}$. An example plate layout for testing of one reference and six sera over six dilutions per sample can be seen in Fig. 4a.

5 Predilute any serum in PRNT/MNA assay diluent that has already been determined to have a neutralizing titer of greater than $1 / 640$. The reference serum is also likely to need predilution to fit within the range of the assay, depending upon the source.

$\triangle$ CRITICAL STEP The first dilution into the plate always gives a $1 / 20$ final dilution, so this must be borne in mind when performing any predilution; e.g., if a dilution series starting at $1 / 640$ is required, perform a predilution of $1 / 32$ (given the additional 1/20 performed in Step 6, the first dilution will be 1/640).

6 To the first two wells of each sample position (i.e., for sample 1, wells C1 and D1), pipette $15 \mu \mathrm{l} /$ well of the sample serum (prediluted serum).

$\triangle$ CRITICAL STEP This dilution is a $1 / 10$ of serum in medium, but later in the procedure (prior to neutralization), an equal volume of virus is added to each well, doubling this initial dilution to $1 / 20$.

7 Continue to add test serum to the remaining positions on the plate.

8 Add the (prediluted) reference serum to wells A1 and B1.

9 With a multichannel pipette set to $75 \mu \mathrm{l}$, double-dilute the serum (six to eight mixes at each column) across the plate, discarding the final $75 \mu \mathrm{l}$ at the end of each row.

$\triangle$ CRITICAL STEP At the end of this step, all wells should contain $75 \mu \mathrm{l}$ except for the two NVC wells G12 and H12, which should contain $150 \mu \mathrm{l}$.

10 Take the diluted serum in the neutralization plates to the containment level 3 laboratory.

Stage II: virus addition and neutralization Timing $1.5 \mathrm{~h}$

! CAUTION Stages II to V involve the use of live SARS-CoV-2 virus and must be performed within a class III safety cabinet within a BSL3 facility by trained and competent operators. 


\begin{tabular}{|c|c|c|c|c|c|c|c|c|c|c|c|c|}
\hline & 1 & 2 & 3 & 4 & 5 & 6 & 7 & 8 & 9 & 10 & 11 & 12 \\
\hline A & \multirow{2}{*}{$\bar{\alpha}$ 品 } & \multirow{2}{*}{ 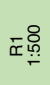 } & \multirow{2}{*}{$\bar{x}_{\stackrel{-}{*}}^{8}$} & \multirow{2}{*}{ 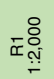 } & \multirow{2}{*}{ 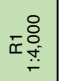 } & \multirow{2}{*}{ 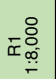 } & \multirow{2}{*}{$\begin{array}{c}54 \\
1: 20\end{array}$} & \multirow{2}{*}{$\begin{array}{c}\text { S4 } \\
1: 40\end{array}$} & \multirow{2}{*}{$\begin{array}{c}\text { S4 } \\
1: 80\end{array}$} & \multirow{2}{*}{$\underset{1: 160}{\mathrm{~S}}$} & \multirow{2}{*}{$\begin{array}{c}54 \\
1: 320\end{array}$} & \multirow{2}{*}{$\begin{array}{c}54 \\
1: 640\end{array}$} \\
\hline B & & & & & & & & & & & & \\
\hline C & \multirow{2}{*}{$\begin{array}{c}S 1 \\
1: 20\end{array}$} & \multirow{2}{*}{$\begin{array}{c}S 1 \\
1: 40\end{array}$} & \multirow{2}{*}{$\begin{array}{c}S 1 \\
1: 80\end{array}$} & \multirow{2}{*}{$\begin{array}{c}S 1 \\
1: 160\end{array}$} & \multirow{2}{*}{$\underset{1: 320}{S 1}$} & \multirow{2}{*}{$\underset{1: 640}{S 1}$} & \multirow{2}{*}{$\begin{array}{c}\text { S5 } \\
1: 20\end{array}$} & \multirow{2}{*}{$\begin{array}{c}\text { S5 } \\
1: 40\end{array}$} & \multirow{2}{*}{$\begin{array}{c}\text { S5 } \\
1: 80\end{array}$} & \multirow{2}{*}{$\begin{array}{c}\text { S5 } \\
1: 160\end{array}$} & \multirow{2}{*}{$\begin{array}{c}\text { S5 } \\
1: 320\end{array}$} & \multirow{2}{*}{$\begin{array}{c}\text { S5 } \\
1: 640\end{array}$} \\
\hline D & & & & & & & & & & & & \\
\hline $\mathrm{E}$ & \multirow{2}{*}{$\begin{array}{c}\mathrm{S} 2 \\
1: 20\end{array}$} & \multirow{2}{*}{$\begin{array}{c}S 2 \\
1: 40\end{array}$} & \multirow{2}{*}{$\begin{array}{c}\mathrm{S} 2 \\
1: 80\end{array}$} & \multirow{2}{*}{$\begin{array}{c}S 2 \\
1: 160\end{array}$} & \multirow{2}{*}{$\begin{array}{c}\text { S2 } \\
1: 320\end{array}$} & \multirow{2}{*}{$\begin{array}{c}\mathrm{S} \\
1: 640\end{array}$} & \multirow{2}{*}{$\begin{array}{c}\mathrm{S6} \\
1: 20\end{array}$} & \multirow{2}{*}{$\begin{array}{c}\mathrm{s6} \\
1: 40\end{array}$} & \multirow{2}{*}{$\begin{array}{c}\text { S6 } \\
1: 80\end{array}$} & \multirow{2}{*}{$\underset{1: 160}{S 6}$} & \multirow{2}{*}{$\underset{1: 320}{56}$} & \multirow{2}{*}{$\begin{array}{c}S 6 \\
1: 640\end{array}$} \\
\hline $\mathrm{F}$ & & & & & & & & & & & & \\
\hline G & \multirow{2}{*}{$\begin{array}{c}\text { S3 } \\
1: 20\end{array}$} & \multirow{2}{*}{$\begin{array}{c}\mathrm{S} 3 \\
1: 40\end{array}$} & & s3 & S3 & S3 & & & & & & \\
\hline $\mathrm{H}$ & & & 1:80 & 1:160 & 1:320 & $1: 640$ & & & niy co & rol (v) & & NVV \\
\hline
\end{tabular}

b

\begin{tabular}{|c|c|c|c|c|c|c|c|c|}
\hline & 1 & 2 & 3 & 5 & 7 & 10 & 11 & 12 \\
\hline A & & 20 & $\begin{array}{c}s 2 \\
1: 20\end{array}$ & $\begin{array}{c}S 3 \\
1: 20\end{array}$ & $\begin{array}{c}S 4 \\
1: 20\end{array}$ & $\begin{array}{c}\text { R1 } \\
\text { 1:250 }\end{array}$ & $\begin{array}{c}\mathrm{R} 2 \\
1: 20\end{array}$ & \\
\hline B & & 41 & $\begin{array}{c}S 2 \\
1: 40\end{array}$ & $\begin{array}{c}S 3 \\
1: 40\end{array}$ & $\begin{array}{c}S 4 \\
1: 40\end{array}$ & $\begin{array}{c}\text { R1 } \\
\text { 1:500 }\end{array}$ & $\begin{array}{c}R 2 \\
1: 40\end{array}$ & \\
\hline c & & 81 & $\begin{array}{c}S 2 \\
1: 80\end{array}$ & $\begin{array}{c}\text { S3 } \\
1: 80\end{array}$ & $\begin{array}{c}S 4 \\
1: 80\end{array}$ & $\begin{array}{c}\mathrm{R} 1 \\
1: 1,000\end{array}$ & $\begin{array}{c}\text { R2 } \\
\text { 1:80 }\end{array}$ & \\
\hline D & & 160 & $\begin{array}{c}\mathrm{S} 2 \\
1: 160\end{array}$ & $\begin{array}{c}\mathrm{S3} \\
1: 160\end{array}$ & $\begin{array}{c}\mathrm{S4} \\
1: 160\end{array}$ & $\begin{array}{c}\text { R1 } \\
1: 2,000\end{array}$ & $\begin{array}{c}\text { R2 } \\
1: 160\end{array}$ & \\
\hline E & & 320 & $\begin{array}{c}\mathrm{S2} \\
1: 320\end{array}$ & $\begin{array}{c}3 \\
1: 320\end{array}$ & $\begin{array}{c}54 \\
1: 320\end{array}$ & $\begin{array}{c}\mathrm{R} 1 \\
1: 4,000\end{array}$ & $\begin{array}{c}\text { R2 } \\
1: 320\end{array}$ & \\
\hline $\mathrm{F}$ & & 540 & $\begin{array}{c}\mathbf{S 2} \\
1: 640\end{array}$ & $\begin{array}{c}3 \\
1: 640\end{array}$ & $\begin{array}{c}4 \\
1: 640\end{array}$ & $\begin{array}{c}\mathrm{R} 1 \\
1: 8,000\end{array}$ & $\begin{array}{c}R 2 \\
1: 640\end{array}$ & \\
\hline G & & 280 & $\begin{array}{c}\mathrm{S} 2 \\
1: 1,280\end{array}$ & $\begin{array}{c}S 3 \\
1: 1,280\end{array}$ & $\begin{array}{c}54 \\
1: 1,280 \\
\end{array}$ & $\begin{array}{c}\mathrm{R} 1 \\
1: 16,000\end{array}$ & $\begin{array}{c}\mathrm{R} 2 \\
1: 1,280\end{array}$ & \\
\hline H & \multicolumn{3}{|c|}{ Cell control (CC) } & \multicolumn{5}{|c|}{ rus control (PC) } \\
\hline
\end{tabular}

Fig. 4 | Typical plate layout of the MNA and the PNA. a, MNA. b, PNA. In this example layout, the reference serum (R1) is prediluted 1/6.25 such that the initial in-plate dilution of $1 / 250$ is achieved. Test sera (S1 to S6) are all tested with no predilution. In the PNA, a second reference (R2) is run without predilution. VOC and PC contain no test serum and are used to determine the foci count and maximum luminance (100\% unneutralized) for the analysis, respectively. NVC and cell control (CC) contain no serum or virus and are used to ensure that cell monolayers are of good quality and that no virus cross-contamination has occurred during assay setup.

11 Thaw a single-use vial of virus using hand heat, and dilute it to the working dilution determined previously (Box 4). Dilute the virus in PRNT/MNA assay diluent; allow for a volume of $9 \mathrm{ml}$ of diluted virus per plate.

12 Using a multichannel pipette, add $75 \mu \mathrm{l} /$ well of the diluted virus to each well of the $\mathrm{V}$-well (neutralization) plate except for the NVC wells (G12 and H12).

13 Stack and seal the plates into a lid-lock plastic box containing several layers of paper towel that have been moistened with $\sim 100 \mathrm{ml}$ of sterile water (for a $5.5 \mathrm{~L}$ box). Incubate the plates at $37^{\circ} \mathrm{C}$ for $1 \mathrm{~h}$ (1.5 h max) to allow neutralization to occur.

! CAUTION Ensure that the sealed box is externally decontaminated before removing it from the safety cabinet or flexible film isolator.

Stage III: virus adsorption Timing $1.5 \mathrm{~h}$

14 In the cell culture laboratory, take the 96-well plate containing the Vero E6 cells into a class II safety cabinet. Using the cell-capable plate washer, run the cell wash program, which should remove $65 \mu \mathrm{l}$ of the maintenance medium from the cells. Then perform two $100 \mu$ l washes with DPBS, leaving the second wash in the wells.

$\triangle$ CRITICAL STEP To prevent the cells from drying out during the assay, a residual volume of $\sim 35 \mu \mathrm{l}$ is always left on the cells. At the end of this step, the wells of the cell plate each contain $\sim 135 \mu \mathrm{l}$ of DPBS.

15 Transfer the washed cell plates to the containment level 3 laboratory, label them to match the numbering used on the neutralization plates and place them in the safety cabinet.

16 Take the box containing the neutralization plates back into the safety cabinet.

17 Using a multichannel pipette, remove $100 \mu \mathrm{l}$ of DPBS from all wells of the cell plate.

$\triangle$ CRITICAL STEP To avoid the risk of cell monolayers drying out in the high airflow of the class III safety cabinet, perform Steps 17 and 18 one plate at a time.

18 Transfer $100 \mu \mathrm{l}$ of the neutralized virus-antibody mixture from the neutralization plate into the cell plate. This is best performed two rows at a time, changing tips after each pair of rows to avoid sample-to-sample contamination. 
19 Stack and seal the plates into the lid-lock plastic box prepared in Step 13. Incubate the plates at $37{ }^{\circ} \mathrm{C}$ for $1 \mathrm{~h}(1.5 \mathrm{~h} \max )$ to allow adsorption to occur.

! CAUTION Ensure that the sealed box is externally decontaminated before removing it from the safety cabinet or flexible film isolator.

Stage IV: removal of inoculum and addition of overlay medium Timing 25 min to $\mathbf{1 ~ h}$

20 Take the box containing the adsorption plates back into the safety cabinet.

21 Remove $100 \mu \mathrm{l}$ of virus-antibody mixture from all wells of the plate. This is best performed two rows at a time, changing tips after each pair of rows to avoid sample-to-sample contamination.

$\triangle$ CRITICAL STEP To avoid the risk of cell monolayers drying out in the high airflow of the class III safety cabinet, perform Steps 21 and 22 one plate at a time.

22 Add $100 \mu \mathrm{l}$ of warmed overlay medium to each well of the plate. This is best performed using the reverse pipetting method owing to the high viscosity of the overlay medium.

23 Stack and seal the plate(s) into the lid-lock plastic box prepared in Step 13. Incubate the plates at $37^{\circ} \mathrm{C}$ for $22-24 \mathrm{~h}$ to allow viral foci to form.

! CAUTION Ensure that the sealed box is externally decontaminated before removing it from the safety cabinet or flexible film isolator.

Stage V: fixing and inactivation of virus Timing $\sim 12 \mathrm{~h}$

24 Take the boxes containing the plates into the MSCIII, and add $100 \mu \mathrm{l}$ of PRNT/MNA fixative to each well of the assay plates.

25 Fumigate the MSCIII overnight with formaldehyde vapor according to local safety protocols.

$\triangle$ CRITICAL STEP The addition of formalin to the wells inactivates the SARS-CoV-2 virus, as well as chemically fixing the cell monolayers. Fumigation should ensure that no residual virus on lids or between wells remains viable. This critical step is an important safety check because, from this point on, the plates are considered noninfectious.

! CAUTION To ensure a good seal of the box, it is good practice to lightly grease the rubber or silicone lid gasket with silicone/vacuum grease after each use.

Stage VI: immunostaining of virus-specific foci $\bigcirc$ Timing $\sim \mathbf{~ d}$

26 Remove fixed medium from all wells using a multichannel pipette and collect into a formaldehyde waste receptacle before removing from the MSCIII.

! CAUTION Formaldehyde is a dangerous chemical. Inactivate waste formaldehyde according to local protocols before disposal.

27 Using a cell-capable plate washer, remove residual fixed medium by performing six $300 \mu$ l washes with distilled water.

$\triangle$ CRITICAL STEP Ensure that the plate washer has been set up such that the aspiration and dispense jets do not come into contact with the fixed cell monolayer and that all aspiration and dispensing speeds are set to the minimum setting.

28 Prepare hydrogen peroxide at $0.3 \%$ (wt/vol) in water from the 30\% (wt/vol) stock, and add $100 \mu \mathrm{l} /$ well to each plate. Allow $11 \mathrm{ml}$ of diluted hydrogen peroxide per plate. Incubate on a plate shaker at ambient temperature for 20-25 min.

$\triangle$ CRITICAL STEP This step removes any residual endogeneous peroxidase activity from the cells which, if not performed, can give rise to background 'spots' on the plates. Hydrogen peroxide has a very short lifespan when diluted in water, so make up this solution immediately before use.

! CAUTION Hydrogen peroxide is harmful, so operators must wear gloves, laboratory coats and laboratory eyewear for this step.

29 Perform two $300 \mu \mathrm{l}$ washes with PBS using the plate washer.

30 Add $100 \mu \mathrm{l} /$ well of diluted anti-SARS-CoV-2 antibody $(1 / 2,000)$ to all wells on the microplates. Allow $11 \mathrm{ml}$ of diluted antibody per plate. Incubate on a plate shaker at ambient temperature for 55-65 min.

31 Perform two $300 \mu \mathrm{l}$ washes with PBS using the plate washer.

32 Add $100 \mu \mathrm{l} /$ well of diluted anti-rabbit IgG conjugate $(1 / 4,000)$ to all wells on the microplates. Allow $11 \mathrm{ml}$ of diluted antibody per plate. Incubate on a plate shaker at ambient temperature for 55-65 min.

33 Perform two $300 \mu \mathrm{l}$ washes with PBS using the plate washer. 
Table 2 | BioSpot counting parameters for the MNA

\begin{tabular}{|c|c|c|c|}
\hline Parameter & Setting & Parameter & Setting \\
\hline Counting mask size (\%) & 85 & Edge Effect Compensation & OFF \\
\hline Normalise Counts of Mask & ON & Weight Function Shape & 0.5 \\
\hline Smart Count & ON & Edge Compensation Level & 1.0 \\
\hline Default sensitivity & 145 & Edge Compensation Before PP & ON \\
\hline Min. SpotSize & 0.0051 Sq.mm & Ring-wise Compensation & OFF \\
\hline Max SpotSize & 0.2012 Sq.mm & Sensitivity Offset & 50 \\
\hline Spot Separation & 10.00 & Border Radius Percentage [\%] & 30.0 \\
\hline Diffuseness & Largest & Border Outline Percentage [\%] & 80.0 \\
\hline $\begin{array}{l}\text { Overdeveloped area } \\
\text { handling }\end{array}$ & Active & Spot Circularity Filtering & OFF \\
\hline Auto Areas & Estimate & Area Weight & 0 \\
\hline Manual Areas & Normalized & Circularity Threshold & 1.5 \\
\hline Objects & $\begin{array}{l}\text { Normal, diffuse spots, } \\
\text { high background }\end{array}$ & $\begin{array}{l}\text { Maximum area of filtered } \\
\text { spots [pix] }\end{array}$ & 500.0 \\
\hline Background balance & ON (80) & Use Global Object Enhancement & OFF \\
\hline Fill Holes & OFF & Method & $\begin{array}{l}\text { Enhanced } \\
\text { Separation }\end{array}$ \\
\hline 'Fiber' Removal & ON & Aperture [pix] & 20 \\
\hline Spots Removal & Inactive & Weight & 3.0 \\
\hline ROI-Touching Removal & OFF & Enhanced Separation Level & 0 \\
\hline
\end{tabular}

34 Allow $11 \mathrm{ml}$ of substrate per plate; prefilter the required amount of TrueBlue substrate using a syringe-mounted $0.45 \mu \mathrm{m}$ filter. Add $100 \mu \mathrm{l}$ of filtered substrate to all wells on the microplates. Incubate on a plate shaker at ambient temperature for $10( \pm 2) \mathrm{min}$.

$\triangle$ CRITICAL STEP If processing a large number of plates, it is better to batch them into groups of four or five plates to avoid leaving the substrate on the plates for too long.

35 Perform four $300 \mu \mathrm{l}$ washes with water using the plate washer.

$\triangle$ CRITICAL STEP It is important to perform this step with water and not PBS, as the stained foci will rapidly fade if PBS is used.

36 Invert the plates and tap them on a paper towel before drying them (generally overnight), face up without lids attached, in a class II safety cabinet or laminar flow hood.

Stage VII: automatic foci counting and neutralization dose determination $\bigcirc$ Timing $\sim \mathbf{1}$

37 Wipe the plate bases with 70\% (vol/vol) isopropanol solution, and load the plate in the correct orientation into the ImmunoSpot analyzer (there is a marking on the plate loading arm adjacent to well A1).

38 Open the BioSpot software to scan and count the stained foci using the parameters in Table 2.

39 Paste the counted data from the Excel spreadsheet file produced by the ImmunoSpot analyzer into the SoftMax Pro protocol file.

$\triangle$ CRITICAL STEP The protocol has been developed to fit the focus count data using a fourparameter logistic regression with upper and lower constraints (0-100\% of the mean VOC counts).

40 Check that the data in SoftMax Pro fulfill the requirements of the MNA assay suitability criteria presented in Table 3. Any plates or samples that do not meet these criteria will require retesting.

\section{Procedure 3: PNA Timing 2 d}

$\triangle$ CRITICAL Before starting this assay, it is essential to inactivate components of the complement system by following the sample-preparation procedure in Box 1. Pseudovirus stock solutions must also be prepared in advance by following the procedure in Box 5. When using a new pseudovirus stock for the first time, sighting experiments must be performed (Box 6).

! CAUTION Perform all steps of this procedure within a class II microbiological safety cabinet.

Stage I: plate setup and serum dilution Timing 2 d

1 Day 0: seed white flat-bottomed 96-well plates with $2.0 \times 10^{5}$ cells $/ \mathrm{ml}(100 \mu \mathrm{l} /$ well $)$ of Vero E6 cells in PNA maintenance medium and incubate overnight at $37{ }^{\circ} \mathrm{C} / 5 \% \mathrm{CO}_{2}$. At the same time, seed one 
Table 3 | System suitability criteria (criteria 1-7) and test sample criteria (criteria 8 and 9) for the MNA

\begin{tabular}{|c|c|}
\hline Criterion & Description \\
\hline 1 & NVC wells $\mathrm{G} 12$ and $\mathrm{H} 12$ average $\leq 5$ foci/well \\
\hline 2 & VOC wells G7 to H11 average $100-250$ foci/well \\
\hline 3 & $\begin{array}{l}\text { VOC wells G7 to H11, at least six of the ten wells must be acceptable (e.g., no cell damage, no } \\
\text { erroneously counted artifacts) }\end{array}$ \\
\hline 4 & $\begin{array}{l}\text { NVC wells G12 and H12, at least one of the two wells must be acceptable (e.g., absence of cell } \\
\text { damage, no erroneously counted artifacts) }\end{array}$ \\
\hline 5 & The reference serum $\mathrm{ND}_{50}$ is within $50-200 \%$ of its stated titer \\
\hline 6 & $\begin{array}{l}\text { Any internal quality control sera are within their stated ranges (this would need to be determined } \\
\text { locally by the implementer) }\end{array}$ \\
\hline 7 & $\begin{array}{l}\text { Both reference and quality control replicates must have yielded a curve (SoftMax Pro GxP) that } \\
\text { crosses the } 50 \% \text { of the VOC }\end{array}$ \\
\hline 8 & Test sample counts all below $50 \%$ of the VOC-sample is strongly neutralizing-dilute and retest \\
\hline 9 & $\begin{array}{l}\text { Test sample counts all above } 50 \% \text { of the VOC-sample is not neutralizing-report as } \\
\leq \text { LLOQ }(1 / 20)\end{array}$ \\
\hline
\end{tabular}

NVC, no-virus control; VOC, virus-only control.

clear plate exactly as for the white plates in parallel; this is used to assess the quality of the cell monolayer in the next step.

$\triangle$ CRITICAL STEP Ensure that the assay is performed in white cell culture plates, as these are critical to assess the luminescence per well while avoiding cross-talk that could occur using transparent plates. Multiple types of plates were evaluated during development, but white cell culture plates were demonstrated to provide the best signal-to-noise ratio.

2 Day 1: ensure that the cells seeded on day 0 are $>80 \%$ confluent, using the cells seeded into the clear plate.

3 Thaw a vial of pseudotyped virus on ice, and keep on ice until ready for dilution.

4 Using a multichannel pipette, add $30 \mu \mathrm{l}$ of PNA assay diluent to rows B to $\mathrm{H}$ of a round-bottomed 96-well plate (the neutralization plate) and $54 \mu$ to the wells of row A.

5 Predilute any serum in PNA assay diluent that has already been determined to have a neutralizing titer of greater than $1 / 1,280$. The reference serum is also likely to need predilution to get it into the range of the assay, depending upon the source.

! CAUTION The first dilution into the plate always gives a 1/20 final dilution, so this must be borne in mind when performing any predilution; e.g., if a dilution series starting at 1/1,280 is required, perform a predilution of $1 / 64$ (given the additional $1 / 20$ performed in Step 7, the first dilution will be $1 / 1,280)$.

6 Add $6 \mu$ of test/reference serum or prediluted test/reference, in duplicate, to the wells in row A of the microplate (Fig. 4b).

7 With a multichannel pipette set to $30 \mu \mathrm{l}$, double-dilute the serum (6 $-8 \times$ mixes at each row) down the plate, discarding the final $30 \mu \mathrm{l}$ after mixing into row $\mathrm{G}$.

$\triangle$ CRITICAL STEP At the end of this step, all wells of the neutralization plate should contain $30 \mu \mathrm{l}$.

Stage II: pseudotyped virus addition and neutralization Timing $\sim 1.5 \mathbf{h}$

8 Perform gentle up-and-down mixing of the thawed pseudotyped virus stock solution before preparing the working dilution.

$\triangle$ CRITICAL STEP Do not vortex the pseudovirus to avoid damaging the virions.

9 Prepare sufficient volume $(\sim 3.5 \mathrm{~mL}$ /plate $)$ of pseudotyped virus working dilution in PNA assay diluent using the dilution ratio predicted in Stage I to yield a target of 150,000 RLUs/well.

10 Into the neutralization plate, add $30 \mu \mathrm{l}$ of diluted virus to all wells of rows A to G and H5 to H12 (PC). To rows $\mathrm{H} 1$ to $\mathrm{H} 4$, add $30 \mu \mathrm{l}$ of PNA assay diluent (cell controls).

11 Replace the lid and incubate the plate(s) for $55-65 \mathrm{~min}$ at $37{ }^{\circ} \mathrm{C} / 5 \% \mathrm{CO}_{2}$. 
Table 4 | Spectramax i3X configuration parameters for the PNA

\begin{tabular}{ll} 
Parameter & Setting \\
\hline Luminescence & LM1 \\
Plate type & 96 Well Corning white (cat. no. 3917) \\
Height & $14.2 \mathrm{~mm}$ \\
Shake & $5 \mathrm{~s}$ \\
ReadOrder & Row \\
Integration & 500 \\
Read Height & $5.38 \mathrm{~mm}$
\end{tabular}

Table 5 | System suitability criteria (criteria 1-4) and test sample criteria (criteria 5 and 6) for the PNA

\begin{tabular}{ll} 
Criterion & Description \\
\hline 1 & Cell control corresponding to $100 \%$ neutralization has an average RLU count $\leq 1,748$ \\
2 & PC has an average RLU count within the acceptance range of $30,604-304,365$ RLU \\
3 & PC has a coefficient of variance (CV) $\leq 25 \%$ \\
4 & Positive quality controls are within their acceptance ranges \\
5 & The intercurve geometric coefficient of variation (GCV) of the sample/control is $\leq 50 \%$ \\
6 & $\begin{array}{l}\text { If a positive quality control has an intercurve GCV }>50 \% \text {, the corresponding plate is automatically } \\
\text { rejected }\end{array}$ \\
\hline
\end{tabular}

PC, pseudotyped versus control.

Stage III: cell monolayer infection and incubation Timing 18-22 h

12 Using a vacuum pump or multichannel pipette, remove the cell growth medium from the flat-bottomed cell seeded plates (cell plate) from Step 1.

$\triangle$ CRITICAL STEP This needs to be performed carefully to avoid scratching or otherwise disturbing the cell monolayers.

13 Using a multichannel pipette, transfer $50 \mu \mathrm{l}$ of the serum/pseudotyped virus mixtures from the neutralization plate into the cell plate.

14 Replace the lid and incubate the cell plates for $18-22 \mathrm{~h}$ at $37{ }^{\circ} \mathrm{C} / 5 \% \mathrm{CO}_{2}$

Stage IV: cell lysis, luminescence measurement and determination of neutralization titers

Timing 18-22 h

15 Thaw and equilibrate to ambient temperature sufficient ONE-Glo EX luciferase assay reagent for all tested plates; allow at least $5.5 \mathrm{ml}$ of diluted luciferase reagent per plate.

$\triangle$ CRITICAL STEP The luciferase assay reagent is light sensitive, so take measures to avoid light exposure and wrap tubes in aluminium foil.

16 Dilute luciferase assay $1 / 2$ in PNA assay diluent.

17 Remove the cell plates from the incubator, and use a vacuum pump or multichannel pipette to remove the cell growth medium.

18 Add $50 \mu \mathrm{l} /$ well of diluted luciferase reagent to all wells of the plate. Incubate the plates for $3 \mathrm{~min}$ at room temperature $\left(20-25^{\circ} \mathrm{C}\right)$ with shaking set at $600 \mathrm{rpm}$.

$\triangle$ CRITICAL STEP Avoid air bubbles; reverse pipetting the luciferase reagent into the plate is a good way to achieve this.

19 Switch on the SpectraMax i3x plate reader and launch SoftMax Pro software (Table 4).

20 Read the luminescence of each plate; the SoftMax Pro protocol determines midpoints of each curve using 4PL regression and outputs each sample's median neutralizing titer $\left(\mathrm{NT}_{50}\right)$. Check that the data in SoftMax Pro fulfill the requirements of the PNA assay suitability criteria listed in Table 5. Any plates or samples that do not meet these criteria will require retesting. 
Box 1, sample preparation for all assays: $1 \mathrm{~h}$

Box 2, production of wild-type virus stocks for PRNT and MNA: $5 \mathrm{~d}$

Box 3, wild-type virus rough and fine sighting experiments for PRNT: 2 weeks

Box 4, wild-type virus semifine sighting and regression experiments for MNA: $3 \mathrm{~d}$

Procedure 1, PRNT: 1 week

Stage I, serum dilution: $1-2 \mathrm{~h}$

Stage II, virus addition and neutralization: $1.5 \mathrm{~h}$

Stage III, virus adsorption: $1.5 \mathrm{~h}$

Stage IV, addition of overlay medium and incubation: $25 \mathrm{~min}$ to $1 \mathrm{~h}$ (followed by $5 \mathrm{~d}$ incubation)

Stage $\mathrm{V}$, fixing and inactivation of virus: $\sim 12 \mathrm{~h}$

Stage VI, staining, counting and scoring of plaque counts: $\sim 1 \mathrm{~d}$

Procedure 2, MNA: $3 \mathrm{~d}$

Stage I, serum dilution: $1-2.5 \mathrm{~h}$

Stage II, virus addition and neutralization: $1.5 \mathrm{~h}$

Stage III, virus adsorption: $1.5 \mathrm{~h}$

Stage IV, removal of inoculum and addition of overlay medium: $25 \mathrm{~min}$ to $1 \mathrm{~h}$

Stage $\mathrm{V}$, fixing and inactivation of virus: $\sim 12 \mathrm{~h}$

Stage VI, immunostaining of virus-specific foci: $\sim 1 \mathrm{~d}$

Stage VII, automatic foci counting and neutralization dose determination: $\sim 1 \mathrm{~d}$

Box 5, creation and production of pseudotyped virus for PNA: $2 \mathrm{~d}$

Box 6, pseudotyped virus dose sighting experiment for PNA assays: $2 \mathrm{~d}$

Procedure 3, PNA: 3 d

Stage I, plate setup and serum dilution: $2 \mathrm{~d}$

Stage II, pseudotyped virus addition and neutralization: $\sim 1.5 \mathrm{~h}$

Stage III, cell monolayer infection and incubation: $18-22 \mathrm{~h}$

Stage IV, cell lysis, luminescence measurement and determination of neutralization titers: $\sim 1.5 \mathrm{~h}$

\section{PRNT}

Following the PRNT procedure, a wild-type virus stock requiring dilutions in the range of $1 / 10$ should have been generated. A single $1 \mathrm{ml}$ vial of this stock should be sufficient to set up four assay plates (one control plate and three sample plates) with an expected VOC of 70 pfu per well. The protocol should yield neutralization curves similar to those shown in Fig. $3 \mathrm{~d}$. Care should be taken with a new reference serum to determine a starting dilution that generates as full a curve as possible (a response of $0-100 \%$ of VOC).

It is good practice to track critical parameters such as VOC counts and reference $\mathrm{ND}_{50}$ using trending worksheets, which can give an indication of where changes have occurred in assay performance and provide assurance that assays are in control and operating consistently. It is convenient to use spreadsheet software such as Microsoft Excel to collect and monitor these trending data. An example of a nonneutralizing and highly neutralizing serum are given in Fig. $3 \mathrm{e}$ and the effects on the graphs demonstrated. Common problems seen after staining the plates can be found in Fig. 7, and a troubleshooting guide can be found in Table 6 .

\section{MNA}

Following the MNA procedure, a wild-type virus stock requiring dilutions in the range of 1/500 or greater should have been generated. A single $1 \mathrm{ml}$ vial of this stock should be sufficient to set up 60 assay plates with an expected VOC of 100-250 countable foci per well. This protocol should yield neutralization curves similar to those shown in Fig. 5b. Implementers should take care with a new reference serum to determine a starting dilution that generates as full a curve as possible (a response of $0-100 \%$ of VOC); an example of a full curve can be seen in Fig. 5b. For clinical trial material, the $\mathrm{EC}_{50}$ generated by the software is reported as the median neutralization dose $\left(\mathrm{ND}_{50}\right)$. The SoftMax protocol has been designed to validate the foci count data and the results of the regression and indicate whether results are reportable or not. Negative sera are reported as less than the lower limit of quantification $(<L L O Q)$, and an example curve can be seen in Extended Data Fig. 6a. Strongly positive sera are reported as greater than the upper limit of quantification (>ULOQ) and may be 


\section{Table 6 | Troubleshooting for the PRNT}

\section{Step} Problem

(Procedure 1)
Staining of monolayer is patchy or uneven
Cells might have been subconfluent on day 1 of the assay
Circular hole in monolayer visible in 24-well plates after staining (Fig. 6b)

4,11
No visible plaques in sample wells where foci are present in the VOC wells of the control plate

Half-moon-shaped areas on 24-well plates with no or few cells visible after staining (Fig. 6a)

Damage to cell monolayer visible after staining
Cells might have dried up during the assay setup

Cells might have been overconfluent on day 1 of the assay. Following washes and further incubation for $5 \mathrm{~d}$, cells can accumulate in the center of the well and detach

The virus titer might have been reduced during setup if a delay results in virus being held at room temperature or at the neutralization incubation step for too long

This effect can be observed if lowabsorption plates are not used for the neutralization plate as virus might bind to the surface of the plate

Highly neutralizing serum

Drying of monolayers during removal of PBS due to removal of too much liquid or length of time taken to replace liquid is too long

Cell plates are being knocked in transit and not being incubated flat during the adsorption step

Where liquid is removed from the cell monolayer with a plate washer or stripette, the tip can scratch the cells away from the plate
Uneven distribution of plaques with more plaques clustered in the center of the well
Following addition of the virus for the adsorption stage, swirling instead of rocking of plates can cause the virus to accumulate in the center of the well

\section{Solution}

- Ensure that cells are $\geq 85 \%$ confluent and are an even monolayer before setting up on day 1

- Ensure that the correct medium was used to plate the cells; i.e., PRNT/MNA maintenance medium was used, not diluent medium

- Ensure that the incubator parameters are within range for cell maintenance and plating

- Prior to harvesting cells for seeding, ensure that the cells are in logarithmic growth (slightly subconfluent)

- Ensure that there is always residual liquid on the cells

- Ensure that the paper towel inside the incubation box is saturated with water

- Ensure that the box seal is sound; this can sometimes be rectified by greasing the seal with silicone/vacuum grease

- Check that the calculations for seeding densities are correct

- Ensure that cells are homogeneous and well suspended following trypsinization to enable accurate counting and calculation of cell density

- Ensure that cells are an even monolayer before setting up on day 1

- Reoptimize cell seeding densities if cells are growing at different rates for specific laboratory setups

- Ensure that the virus is thawed quickly using hand heat only

- Use the virus immediately upon thawing

Ensure that the correct low-binding 96-well plates are used for the neutralization plate setup (e.g., Thermo Fisher Scientific, cat. no. 249935)

Retest the serum, starting at a higher starting dilution e.g., 1/320

Ensure that sufficient volume is left on cells during removal of PBS. If the removal of PBS is taking too long, rock the remaining fluid over the cells to reflood the well and prevent drying

Ensure that the plates are incubated flat, particularly during the adsorption step where the volume of liquid is low

- During these steps, take care not to touch the cell surface with the stripette. The plate should be tilted and the tip of the stripette submerged to just above the base of the plate

- Ensure that the washer aspiration and dispense settings are at their slowest/gentlest levels

- Ensure that the washer nozzle offsets are set so that the nozzles do not touch the base of the plate

- If possible, adjust the nozzle offsets to aspirate and dispense at the extreme edge of each well rather than the center

Ensure that plates are rocked following addition of virus, not swirled 
Table 6 (continued)

\begin{tabular}{|c|c|c|c|}
\hline $\begin{array}{l}\text { Step } \\
\text { (Procedure 1) }\end{array}$ & Problem & Possible reason & Solution \\
\hline \multirow[t]{2}{*}{20} & $\begin{array}{l}\text { Uneven distribution of plaques } \\
\text { with clustering of plaques } \\
\text { consistently to one side of } \\
\text { the well }\end{array}$ & $\begin{array}{l}\text { Plates could have been incubated at an } \\
\text { angle during the adsorption step }\end{array}$ & $\begin{array}{l}\text { Ensure that plates are stacked evenly prior to } \\
\text { incubation }\end{array}$ \\
\hline & & The incubator might not be level & $\begin{array}{l}\text { Adjust the incubator and check the shelves } \\
\text { are level }\end{array}$ \\
\hline 22 & $\begin{array}{l}\text { Plaques have a large or comet- } \\
\text { shaped morphology (Fig. } 6 \mathrm{c} \text { ) }\end{array}$ & $\begin{array}{l}\text { Viscosity of CMC can vary between } \\
\text { different batches from the supplier }\end{array}$ & $\begin{array}{l}\text { Reoptimize the \% (wt/vol) of CMC used in the } \\
\text { overlay medium by running a VOC plate with a } \\
\text { range of CMC concentrations. The overlay medium } \\
\text { should be of a consistency that can be easily } \\
\text { transferred by stripette but thick enough to contain } \\
\text { the virus to allow a well-defined plaque to form }\end{array}$ \\
\hline \multirow[t]{2}{*}{35,36} & $\begin{array}{l}\text { A neutralization graph is not } \\
\text { generated by } R\end{array}$ & $\begin{array}{l}\text { The worksheet for analysis was not } \\
\text { saved as a .csv file }\end{array}$ & Ensure that the worksheet is saved as a .csv file \\
\hline & & $\begin{array}{l}\text { The layout of the .csv file is not as } \\
\text { described in Step } 35\end{array}$ & $\begin{array}{l}\text { Ensure that the worksheet is set out as described in } \\
\text { Step } 35\end{array}$ \\
\hline
\end{tabular}

a

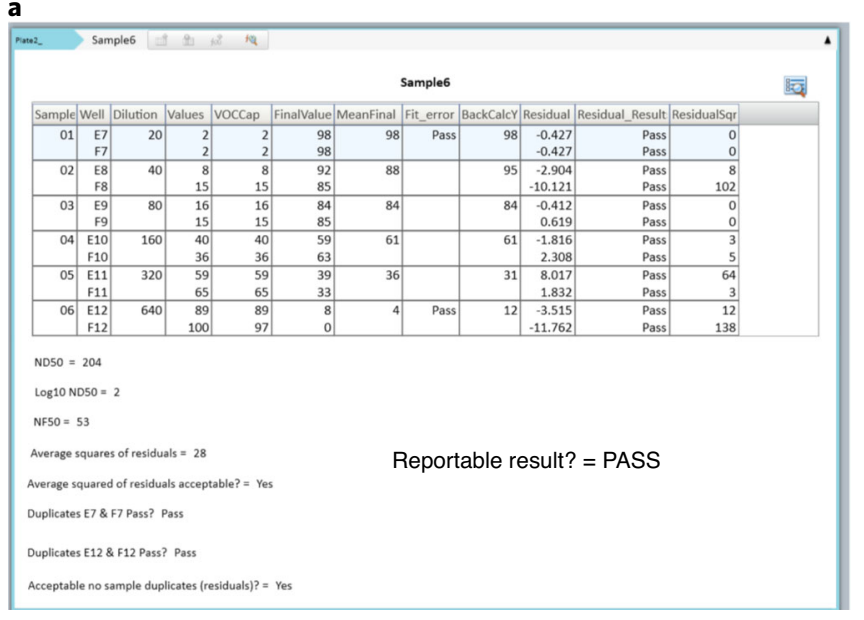

b
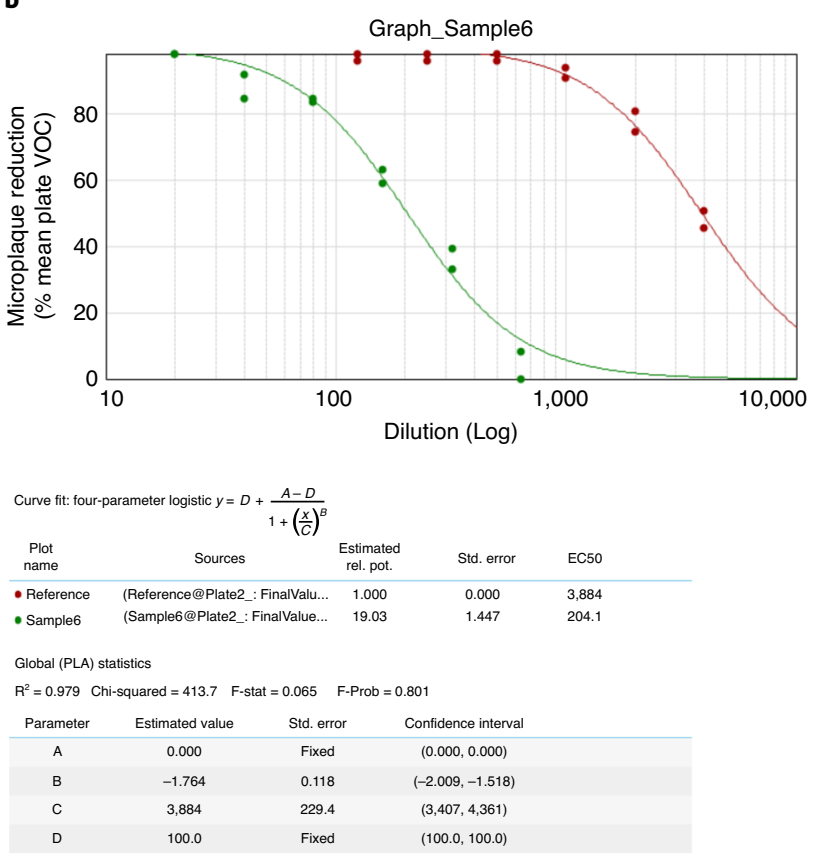

Fig. 5 | Example data generated by the SoftMax Pro protocol. a, The raw foci counts are shown in the Values column, and the percentage neutralization (of the VOC average foci count) is shown in the MeanFinal column. b. An example four-parameter regression output from the SoftMax Pro protocol. The top panel shows the sample regression curve (green) against the reference curve (red). Neutralization doses (ND50) are shown in the column EC50; reference $=3,884$ and sample $=204.1$.

retested at a higher initial starting dilution to determine the $\mathrm{ND}_{50}$; an example of such a strongly neutralizing serum can be seen in Extended Data Fig. 6b. Common problems seen after imaging the plates can be found in Fig. 7, and a troubleshooting guide can be found in Table 7.

It is good practice to track critical parameters using trending worksheets, which can give an indication of where changes have occurred in assay performance and provide assurance that assays are in control and operating consistently. Useful parameters to track include VOC counts, reference $\mathrm{ND}_{50}$ and measures of operator performance such as average square residuals of the $4 \mathrm{PL}$ fits. It is 


\section{Table 7 | Troubleshooting for the MNA}

Step

Problem

(Procedure 2)
Cell plate edge wells (rows $A$ and H columns 1 and 12) appear to have no cells, fewer cells or damaged monolayers

5,39

$14,27,29$

$31,33,35$

Scanned well images show small areas of damage near to the 12 or 6 o'clock positions (Fig. 6g)

Excessive focus size causing spot recognition issues on the $C T L$ scanner/BioSpot software (Fig. 6f)

Well area obscured with darkly staining material (Fig. 6i)

\section{Possible reason}

Solution
Drying of monolayers during incubation due to insufficient humidity in the box and/or loss of humidity

Highly neutralizing serum

Washing Steps 14, 27, 29, 31 33, 35 might have washed patches of the cell monolayers off the plates

For Steps 17, 21 and 26, where liquid is removed from the cell monolayer with a pipette, the pipette tips can scratch the cells away from the plate

Viscosity of CMC in the overlay can vary between different batches from the supplier

Foreign matter such as fibers in wells

Foreign matter/salt residue on the bottom of the plate
- Ensure that the paper towel inside the incubation box is saturated with water

- Ensure that the box seal is sound; this can sometimes be rectified by greasing the seal with silicone/ vacuum grease

Retest the serum, starting the dilutions at a higher starting dilution (e.g., 1/320)

- Ensure that the washer aspiration and dispense settings are at their slowest/gentlest levels

- Ensure that the washer nozzle offsets are set so that the nozzles do not touch the base of the plate

- If possible, adjust the nozzle offsets to aspirate and dispense at the extreme edge of each well rather than the center

During these steps, take care not to touch the tips to the cell surface of the plate. Instead, the tips should be submerged to just above the base of the plate

Reoptimize the \% (wt/vol) of CMC used in the overlay medium by running a $\mathrm{VOC}$ plate with a range of CMC concentrations. The overlay medium should be of a consistency that can be easily transferred using $300 \mu$ tips on a multichannel pipette viscous enough to contain the virus to allow a well-defined, isolated foci to form

- Only tap dry plates on lint-free paper towel - Dry plates in MSCII or laminar flow cabinet Wipe the plate bases with $70 \%$ isopropanol solution and rescan/recount

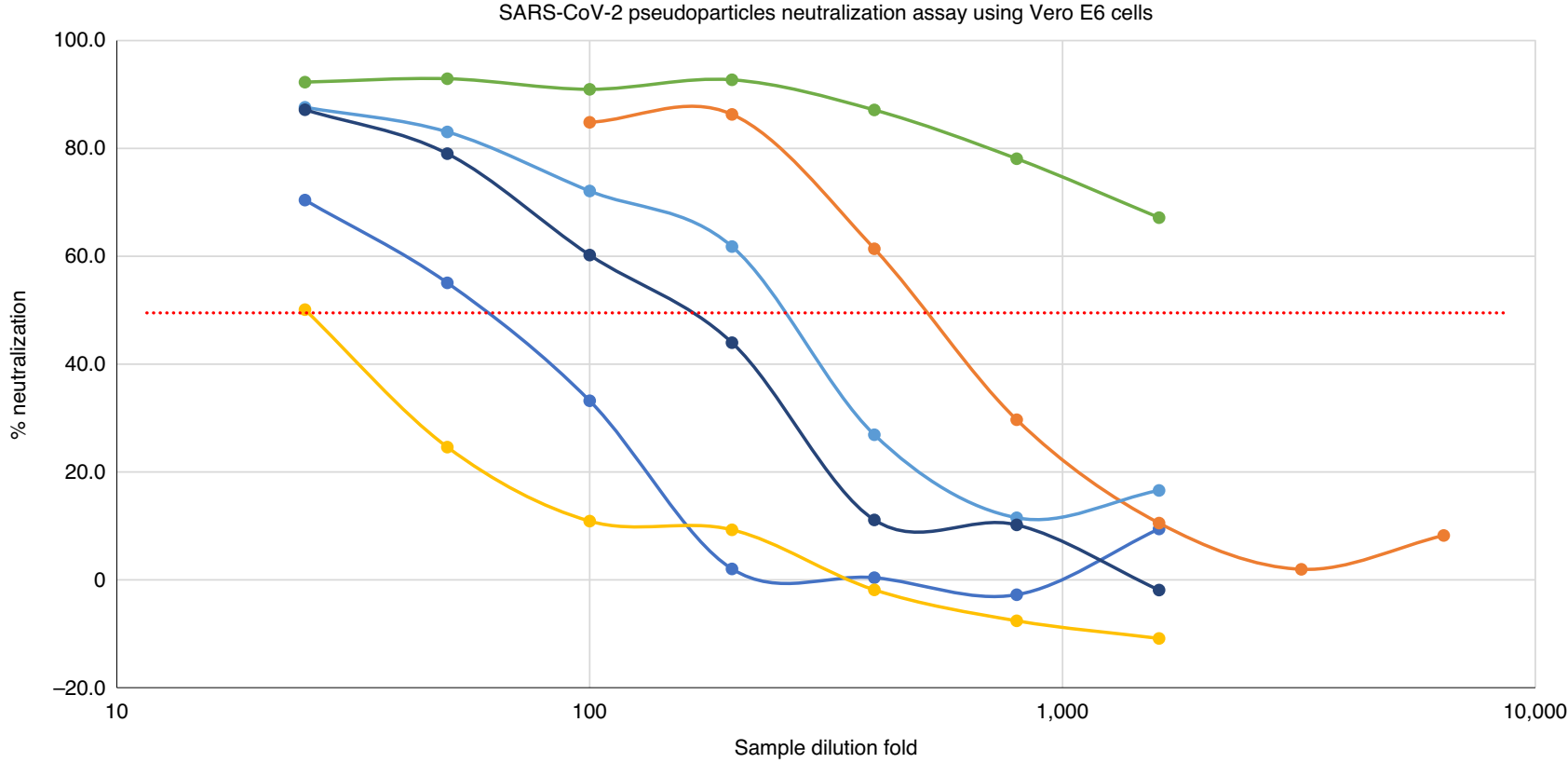

Fig. 6 | Typical neutralization curves expected from the PNA. Poorly neutralizing sera (yellow) do not cross the dotted line corresponding to $50 \%$ of the luminance value of the pseudotyped virus control. Sera in the test range (blue and orange) all cross the 50\% neutralization and yield reportable titers. Highly neutralizing sera (green) do not cross the $50 \%$ neutralization and must be retested at a higher initial dilution. 


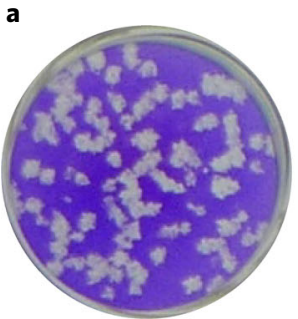

e

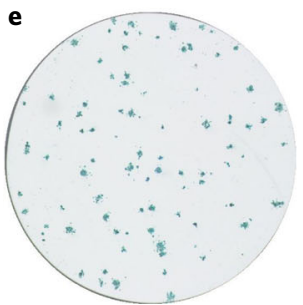

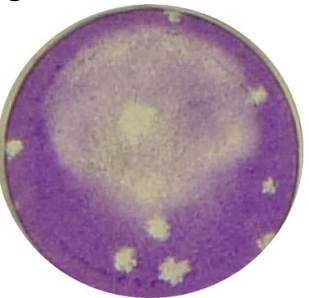

f

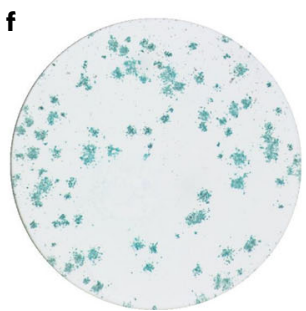

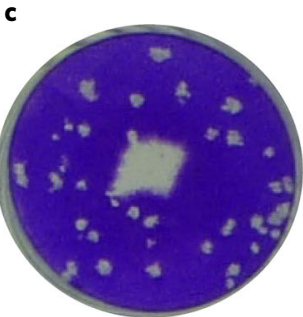

g

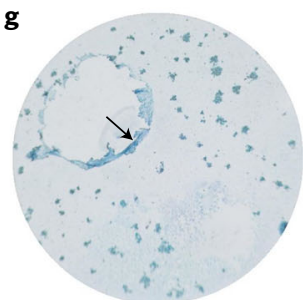

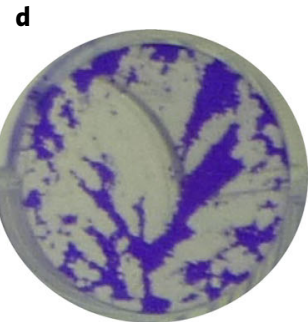

h

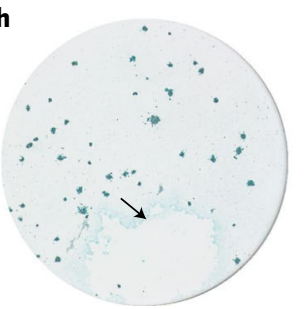

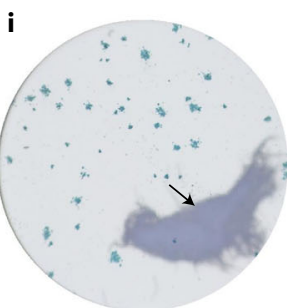

Fig. 7 | Examples of potential issues that can occur during the PRNT and MNA assays. a-d, PRNT. e-i, MNA. a, Typical PRNT plaque image from a successful experiment. b, Drying of monolayers during assay setup can result in 'half-moon' or patchy staining. c, When monolayers are overconfluent, cells can accumulate in the middle of the wells and detach during assay setup. d, If CMC overlay is not viscous enough, plaques can have a large or comet-shaped morphology. e, Typical MNA foci image from a successful experiment. f, Enlarged MNA foci caused by excessive incubation or insufficiently viscous overlay. $\mathbf{g}-\mathbf{h}$, Tears in the monolayer caused by 'rough' pipetting (g) or incorrect washer settings (h). $\mathbf{i}$, Foreign material obscuring well.

Table 8 | Troubleshooting for the PNA

\begin{tabular}{|c|c|c|c|}
\hline $\begin{array}{l}\text { Step } \\
\text { (Procedure 3) }\end{array}$ & Problem & Possible reason & Solution \\
\hline 1 & $\begin{array}{l}\text { Luminescence observed in cell } \\
\text { control }\end{array}$ & Possible cross-talk & $\begin{array}{l}\text { Ensure that you are using the recommended } \\
\text { white plate }\end{array}$ \\
\hline \multirow[t]{4}{*}{$1,2,3,15$} & $\begin{array}{l}\text { Low level of luminescence } \\
\text { observed ( }<75,000 \text { RLUs/well) }\end{array}$ & $\begin{array}{l}\text { Cell density too high during cell } \\
\text { maintenance }\end{array}$ & $\begin{array}{l}\text { Ensure that cell confluency is always below } 90 \% \\
\text { during cell passage }\end{array}$ \\
\hline & & Titration erroneous & Reperform a virus titration \\
\hline & & Pseudotyped virus was vortexed & Thaw the virus on ice and mix slowly by inversion \\
\hline & & $\begin{array}{l}\text { Issue with the luminescence } \\
\text { substrate }\end{array}$ & $\begin{array}{l}\text { Use a new bottle or another lot of luminescence } \\
\text { substrate }\end{array}$ \\
\hline \multirow[t]{3}{*}{$1,2,7,12,13$} & Intercurve CV >50\% & Issue with multichannel pipette & $\begin{array}{l}\text { Calibrate multichannel pipette removed from each } \\
\text { well. Ensure that the washer aspiration and } \\
\text { dispense settings are at their slowest/ } \\
\text { gentlest levels }\end{array}$ \\
\hline & & $\begin{array}{l}\text { Insufficient pipette mixing to ensure } \\
\text { a homogeneous mix }\end{array}$ & $\begin{array}{l}\text { Perform a minimum of five up-and-down pipette } \\
\text { mixes prior to transferring the contents of } \\
\text { the wells }\end{array}$ \\
\hline & & Cell layer not homogeneous & $\begin{array}{l}\text { As the assay is performed in white plates, the } \\
\text { quality of the cell layer cannot be assessed. } \\
\text { However, mock assessment using methylene blue } \\
\text { can be performed to verify that the cell layer is not } \\
\text { impacted by the manner medium }\end{array}$ \\
\hline 5,20 & $\begin{array}{l}\text { Not able to determine the titer (all } \\
\text { data points are above } 50 \% \\
\text { neutralization) }\end{array}$ & Highly neutralizing serum & $\begin{array}{l}\text { Retest the serum, starting at a higher starting } \\
\text { dilution e.g., } 1 / 100 \text { or } 1 / 1,000\end{array}$ \\
\hline
\end{tabular}

convenient to use spreadsheet software such as Microsoft Excel to collect, graphically summarize and monitor these trending data.

\section{PNA}

Following the PNA procedure, a pseudotyped VSV-spike stock requiring dilutions in the range of $1 / 50$ should have been generated. A single $1 \mathrm{ml}$ vial of this stock should be sufficient to set up $\sim 15$ assay plates (60 samples) with an expected VOC of 150,000 RLUs per well. This range was calculated 
based on the results of runs performed by multiple analysts over several days on a single instrument. However, if additional instruments or critical reagents are to be used, these will need to be bridged. It should be noted that the range of RLUs should be amended only if it can be shown that this does not alter the titers obtained. The PNA protocol should yield neutralization curves similar to those shown in Fig. 6. Care should be taken with a new reference serum to determine a starting dilution that generates as full a curve as possible (a response of $0-100 \%$ of the VOC).

It is good practice to track critical parameters using trending worksheets, which can give an indication of where changes have occurred in assay performance and provide assurance that assays are in control and operating consistently. An example of a nonneutralizing and highly neutralizing serum is given in Fig. 6 and the effects on the graphs demonstrated. A troubleshooting guide for this assay can be found in Table 8 .

\section{Reporting Summary}

Further information on research design is available in the Nature Research Reporting Summary linked to this article.

\section{References}

1. Lim, Y. X., Ng, Y. L., Tam, J. P. \& Liu, D. X. Human coronaviruses: a review of virus-host interactions. Diseases https://doi.org/10.3390/diseases4030026 (2016).

2. Agency, E. M. ICH Topic Q 2 (R1) Validation of analytical procedures: text and methodology (CPMP/ICH/ 381/95) (EMA 1995).

3. Zheng, J. SARS-CoV-2: an emerging coronavirus that causes a global threat. Int. J. Biol. Sci. 16, 1678-1685 (2020).

4. Campi-Azevedo, A. C. et al. 17DD yellow fever revaccination and heightened long-term immunity in populations of disease-endemic areas, Brazil. Emerg. Infect. Dis. 25, 1511-1521 (2019).

5. Cohen, B. J., Doblas, D. \& Andrews, N. Comparison of plaque reduction neutralisation test (PRNT) and measles virus-specific IgG ELISA for assessing immunogenicity of measles vaccination. Vaccine 26, 6392-6397 (2008).

6. Eyal, O. et al. Development of a tissue-culture-based enzyme-immunoassay method for the quantitation of anti-vaccinia-neutralizing antibodies in human sera. J. Virol. Methods 130, 15-21 (2005).

7. Duan, K. et al. Effectiveness of convalescent plasma therapy in severe COVID-19 patients. Proc. Natl Acad. Sci. USA 117, 9490-9496 (2020).

8. Chi, X. et al. A neutralizing human antibody binds to the N-terminal domain of the Spike protein of SARSCoV-2. Science 369, 650-655 (2020).

9. Liu, L. et al. Potent neutralizing antibodies against multiple epitopes on SARS-CoV-2 spike. Nature 584, $450-456$ (2020).

10. Zhao, H. et al. Tocilizumab combined with favipiravir in the treatment of COVID-19: a multicenter trial in a small sample size. Biomed. Pharmacother. 133, 110825 (2021).

11. Cohen, B. J., Audet, S., Andrews, N., Beeler, J. \& WHO Working Group on Measles Plaque Reduction Neutralization Test. Plaque reduction neutralization test for measles antibodies: description of a standardised laboratory method for use in immunogenicity studies of aerosol vaccination. Vaccine 26, 59-66 (2007).

12. Fournier, C. et al. A focus reduction neutralization assay for hepatitis $\mathrm{C}$ virus neutralizing antibodies. Virol. J. 4, 35 (2007).

13. Simoes, M. et al. Evaluation of accuracy and reliability of the plaque reduction neutralization test (microPRNT) in detection of yellow fever virus antibodies. Biologicals 40, 399-404 (2012).

14. Vaidya, S. R. et al. Development of a focus reduction neutralization test (FRNT) for detection of mumps virus neutralizing antibodies. J. Virol. Methods 163, 153-156 (2010).

15. Steeds, K. et al. Pseudotyping of VSV with Ebola virus glycoprotein is superior to HIV-1 for the assessment of neutralising antibodies. Sci. Rep. 10, 14289 (2020).

16. National Institute for Biological Standards and Control (NIBSC). Coronavirus (COVID-19)-related research reagents available from the NIBSC. https://www.nibsc.org/science_and_research/idd/cfar/covid-19_ reagents.aspx

17. Folegatti, P. M. et al. Safety and immunogenicity of the ChAdOx1 nCoV-19 vaccine against SARS-CoV-2: a preliminary report of a phase 1/2, single-blind, randomised controlled trial. Lancet 396, 467-478 (2020).

18. Ramasamy, M. N. et al. Safety and immunogenicity of ChAdOx $1 \mathrm{nCoV}-19$ vaccine administered in a primeboost regimen in young and old adults (COV002): a single-blind, randomised, controlled, phase $2 / 3$ trial. Lancet https://doi.org/10.1016/S0140-6736(20)32466-1 (2020).

19. Sadoff, J. et al. Safety and immunogenicity of the Ad26.COV2.S COVID-19 vaccine candidate: interim results of a phase 1/2a, double-blind, randomized, placebo-controlled trial. Preprint at medRxiv https://doi.org/10. 1101/2020.09.23.20199604 (2020).

20. Ryan, K. A. et al. Dose-dependent response to infection with SARS-CoV-2 in the ferret model: evidence of protection to re-challenge. Preprint at bioRxiv https://doi.org/10.1101/2020.05.29.123810 (2020). 
21. Salguero, F. J. et al. Comparison of Rhesus and Cynomolgus macaques as an authentic model for COVID-19. Preprint at bioRxiv https://doi.org/10.1101/2020.09.17.301093 (2020).

22. Smith, T. R. F. et al. Immunogenicity of a DNA vaccine candidate for COVID-19. Nat. Commun. 11, 2601 (2020).

23. Tree, J. A. et al. Unfractionated heparin inhibits live wild-type SARS-CoV-2 cell infectivity at therapeutically relevant concentrations. Br. J. Pharmacol. https://doi.org/10.1111/bph.15304 (2020).

24. Huo, J. et al. Neutralization of SARS-CoV-2 by destruction of the prefusion spike. Cell Host Microbe 28, 497 (2020).

25. Ejemel, M. et al. A cross-reactive human IgA monoclonal antibody blocks SARS-CoV-2 spike-ACE2 interaction. Nat. Commun. 11, 4198 (2020).

26. Zhou, D. et al. Structural basis for the neutralization of SARS-CoV-2 by an antibody from a convalescent patient. Nat. Struct. Mol. Biol. 27, 950-958 (2020).

27. Nie, J. et al. Quantification of SARS-CoV-2 neutralizing antibody by a pseudotyped virus-based assay. Nat. Protoc. 15, 3699-3715 (2020).

28. Tandon, R. et al. Effective inhibition of SARS-CoV-2 entry by heparin and enoxaparin derivatives. Preprint at bioRxiv https://doi.org/10.1101/2020.06.08.140236 (2020).

29. Armitage, P. \& Allen, I. Methods of estimating the LD 50 in quantal response data. J. Hyg. (Lond) 48, 298-322 (1950).

30. Amanat, F. et al. An in vitro microneutralization assay for SARS-CoV-2 serology and drug screening. Curr. Protoc. Microbiol. 58, e108 (2020).

31. Vanderheiden, A. et al. Development of a rapid focus reduction neutralization test assay for measuring SARSCoV-2 neutralizing antibodies. Curr. Protoc. Immunol. 131, e116 (2020).

\section{Acknowledgements}

The authors thank C. Cardonnel, field application scientist at Molecular Devices, for her assistance in developing the SoftMax Pro formulae and protocols for the microneutralization assay. The PNA elements of this work were supported by the Global Health Vaccine Accelerator Platforms (GH-VAP) and the Coronavirus Immunotherapy Consortium (CoVIC) funded by BMGF.

\section{Author contributions}

K.R.Be. optimized and developed general growth and virological techniques at BSL3 for SARS-CoV-2. K.R.Be., L.G., L.M., J.S.-J. and K.T. performed statistical analyses and the development and implementation of curve-fitting algorithms. K.R.Be, N. S. C., L. M., N. B., I. S. and K. J. G. were responsible for development and qualification of MNA. K.R.Be, L. M., K. R. Bu and K.J.G were responsible for development of the PRNT. L.G., J.S.-J., N.S.-A. and G.K. were responsible for development and qualification of the PNA. K.R.Be., N. S. C., L. M., N. B., I. S., K. R. Bu, H. E. H., K. J. G., E. B., L. A., S. L., E. J. P., P. J. B. and K.T. performed assays at BSL3 and/or generated data for clinical trials. B.H., M.C., S.F. and S.C. provided scientific oversight. S.C. coordinated the development and qualification of PRNT and MNA. K.R.Be., N.S.C. and L.G wrote and contributed equally to the manuscript. All authors critically reviewed and approved the manuscript.

\section{Competing interests}

The authors declare no competing interests.

\section{Additional information}

Extended data is available for this paper at https://doi.org/10.1038/s41596-021-00536-y.

Supplementary information The online version contains supplementary material available at https://doi.org/10.1038/s41596-021-00536-y. Correspondence and requests for materials should be addressed to K.R.B.

Peer review information Nature Protocols thanks Youchun Wang and the other, anonymous reviewer(s) for their contribution to the peer review of this work.

Reprints and permissions information is available at www.nature.com/reprints.

Publisher's note Springer Nature remains neutral with regard to jurisdictional claims in published maps and institutional affiliations.

Received: 7 December 2020; Accepted: 17 March 2021;

Published online: 23 April 2021

\section{Related links}

Key references using this protocol

Folegatti, P. M. et al. Lancet 396, 467-478 (2020): https://doi.org/10.1016/S0140-6736(20)31604-4

Ramasamy, M. N. et al. Lancet 396, 1979-1993 (2020): https://doi.org/10.1016/S0140-6736(20)32466-1

Sadoff, J. et al. Preprint at medRxiv (2020): https://doi.org/10.1101/2020.09.23.20199604 
NATURE PROTOCOLS

PROTOCOL

\begin{tabular}{|c|c|}
\hline Qualification Parameter & Result \\
\hline Specificity & $\begin{array}{l}100 \% \text { specificity for SARS-CoV-2 convalescent giving values greater than } 1 / 20 \text { and negative (pre-2019) sera }<1 / 20 \text {. } \\
\text { Dilution of positive sera 1:1 in sera positive for non-SARS-CoV- } 2 \text { viral diseases demonstrated the expected recovery. }\end{array}$ \\
\hline Linearity & $\begin{array}{l}\mathrm{R} 2=0.86 \\
\text { Slope }=0.91 \\
\text { Demonstrated over } \mathrm{ND}_{50} 58 \text { to } 1858^{*} \text {, the assessed linear range of the assay }\end{array}$ \\
\hline Relative Accuracy & $\begin{array}{l}\text { Percentage relative recovery ranged from } 61 \text { to } 198 \% \text { and percentage relative error ranged from }-39 \text { to } 98 \% \text { for } 91 \% \text { of the mean sample } \\
\text { points (over } \mathrm{ND}_{50} \\
58 \text { to } 1858 \text {, the assessed linear range) }\end{array}$ \\
\hline Precision & $\begin{array}{l}\text { Repeatability \%CV: } 35.4 \% \\
\text { Intermediate Precision: \%CV: } 46.5 \% \text { (including diluted samples) } \\
\text { Repeatability \%CV: } 28.1 \% \\
\text { Intermediate Precision \%CV: } 43.0 \% \text { (undiluted samples) }\end{array}$ \\
\hline Analytical range & ND50 58 to $1858^{*}$ (sample reportable value range) \\
\hline $\begin{array}{l}\text { Lower Limit of quantification (LLOQ) and } \\
\text { Upper Limit of quantification (ULOQ) }\end{array}$ & $\mathrm{LLOQ}=1 / 58 ; \mathrm{ULOQ}=1 / 1858^{*}$ \\
\hline Lower limit of detection (LLOD) ${ }^{\dagger}$ & The theoretical LLOD is ND50 of 20 constrained by the $50 \%$ curve value. The lowest ND50 detected in Qualification was 21 \\
\hline \multicolumn{2}{|c|}{$\begin{array}{l}\text { * It should be noted that the } L O Q \text { values are the expected geometric mean ND50s obtained from a data set limited by sera available at the time of qualification and the true values may } \\
\text { differ; this value is presented for information only. } \\
\text { T There is no upper limit of detection (ULOD) as a sample with a very high ND50 can be tested at a higher initial dilution if necessary. Dilutability of up to } 1 / 400 \text { sera sample in assay media } \\
\text { was examined in the Qualification although the upper limits of this was not explored due to lack of available characterised high titre samples. }\end{array}$} \\
\hline
\end{tabular}

Extended Data Fig. 1 | Qualification findings for microneutralization assay (MNA). 


\begin{tabular}{|c|c|}
\hline Qualification Parameter & Result \\
\hline Precision & $\begin{array}{l}\text { Geometric coefficient of variation (GCV) of repeatability: } 20.5 \% \\
\text { Overall GCV of intermediate precision: } 50.2 \% \text {; and of intermediate precision within the quantification range: } 49.9 \% \text {. }\end{array}$ \\
\hline Dilutional Linearity and Relative Accuracy & $\begin{array}{l}\text { The relative accuracies for at least } 80 \% \text { of samples fell within the acceptance limits of }[0.5-2.0] \text {. } \\
\text { Slope: }-1.0461 \\
R^{2} \text { value: } 0.9862\end{array}$ \\
\hline $\begin{array}{l}\text { Lower and Upper Limit of Quantification } \\
\text { (LLOQ \& ULOQ) }\end{array}$ & The LLOQ and ULOQ were respectively determined from results obtained from the precision and linearity assessments to be 33 and 6006. \\
\hline Specificity & $\begin{array}{l}\text { For homologous antigen, the \%inhibition observed was } \geq 75 \% \text { for }<80 \% \text { of the results. For MERS-CoV spike glycoprotein and SARS-CoV-2 } \\
\text { nucleocapsid, the \%inhibition observed was within } \pm 50 \% \text { for } 100 \% \text { and } 73 \% \text { of the results, respectively. }\end{array}$ \\
\hline Matrix Interference & $\begin{array}{l}\text { For lipemia and icterus, there is no interference at levels of } 3+\text {. For hemolysis, there is no interference at levels of } 3+\text { for samples with a starting } \\
\text { dilution of } 100 \text { and } 1000 \text { but levels of } 1+, 2+\text { and } 3+\text { interfere for samples with a starting dilution of } 10 .\end{array}$ \\
\hline Freeze/Thaw and Bench Top Stability & $\begin{array}{l}\text { Geometric Mean Ratio (GMR) for } 5 \text { freeze/thaw cycles: } 0.82 \\
\text { GMR for } 10 \text { freeze/thaw cycles: } 0.69 \text { ( }<0.80 \text { therefore unacceptable) } \\
\text { The maximum number of permissible freeze/thaw cycles per sample is therefore } 5 .\end{array}$ \\
\hline $\begin{array}{l}\text { Robustness (Maximum Number of Plates } \\
\text { per Assay Run) }\end{array}$ & $\geq 80 \%$ of plates had GMRs within 0.80 to 1.25 . The maximum number of plates is 20 (for stacks of a maximum of 3 plates). \\
\hline Quality Control Range Determination & $\begin{array}{l}\text { The determined SARS-CoV-2 PNA QC ranges were }[1,912-5,750] \text { for the high positive control (SARSCOV2/Neutra/CTRL-2/2020) and [139-383] } \\
\text { for the low positive control (SARSCOV2/Neutra/CTRL-1/2020). }\end{array}$ \\
\hline $\begin{array}{l}\text { Pseudovirus Control Range and Cell } \\
\text { Control Threshold Determination }\end{array}$ & The determined pseudovirus control range was $[30,604 \mathrm{RLU}-304,365 \mathrm{RLU}]$ whereas the determined cell control threshold was $1,748 \mathrm{RLU}$. \\
\hline
\end{tabular}

Extended Data Fig. 2 | Qualification findings for pseudotyped virus neutralization assay (PNA). 


\section{NATURE PROTOCOLS}

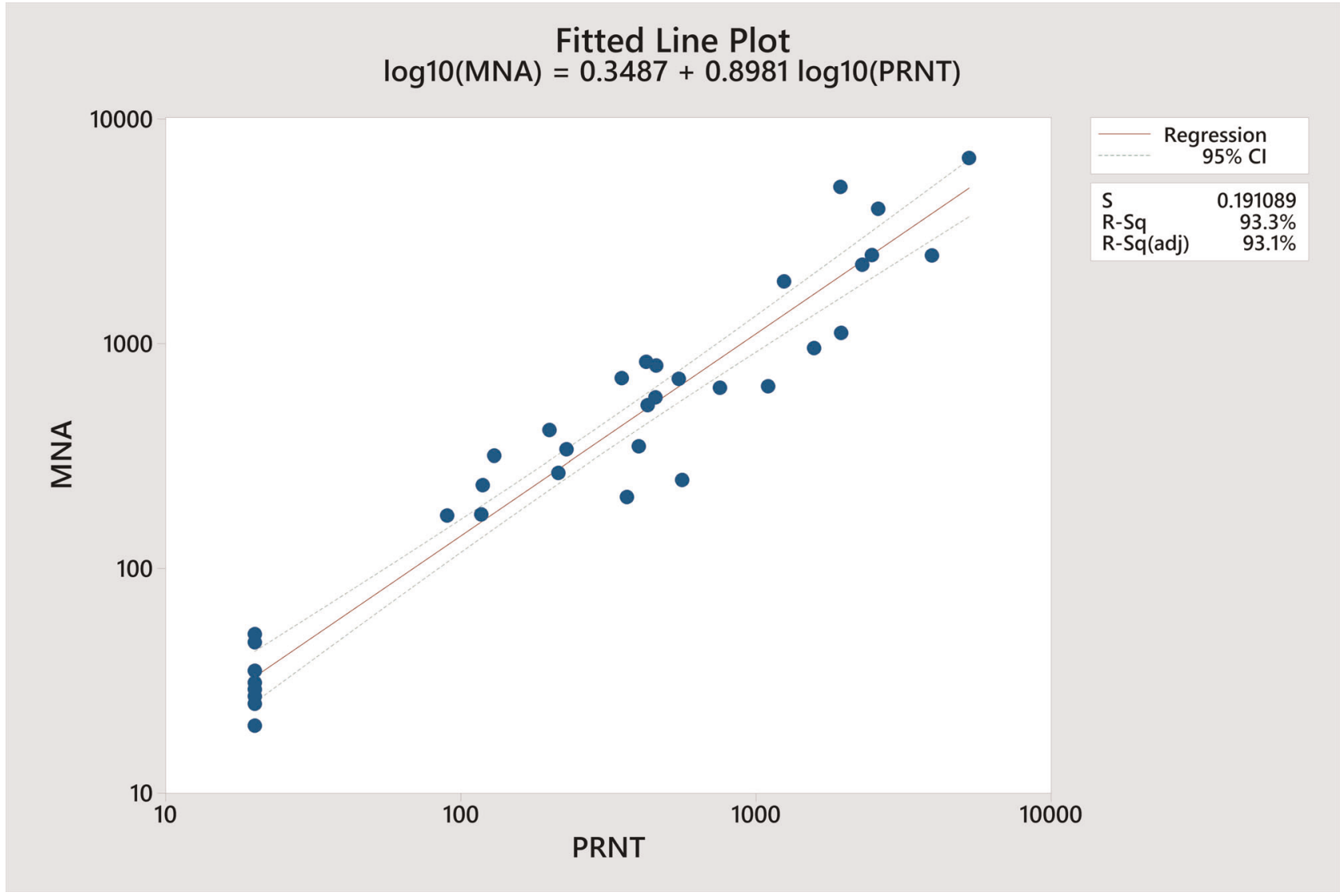

Extended Data Fig. 3 | Showing correlation (MiniTab v19) of the ND $_{50}$ values of panel of 37 convalescent human sera tested in both PRNT and MNA. The two assays show excellent correlation (Pearson correlation $r=0.963 ; p<0.001$ ) given that both assays are wild-type virus bioassays performed at BSL3. 


\section{PROTOCOL}

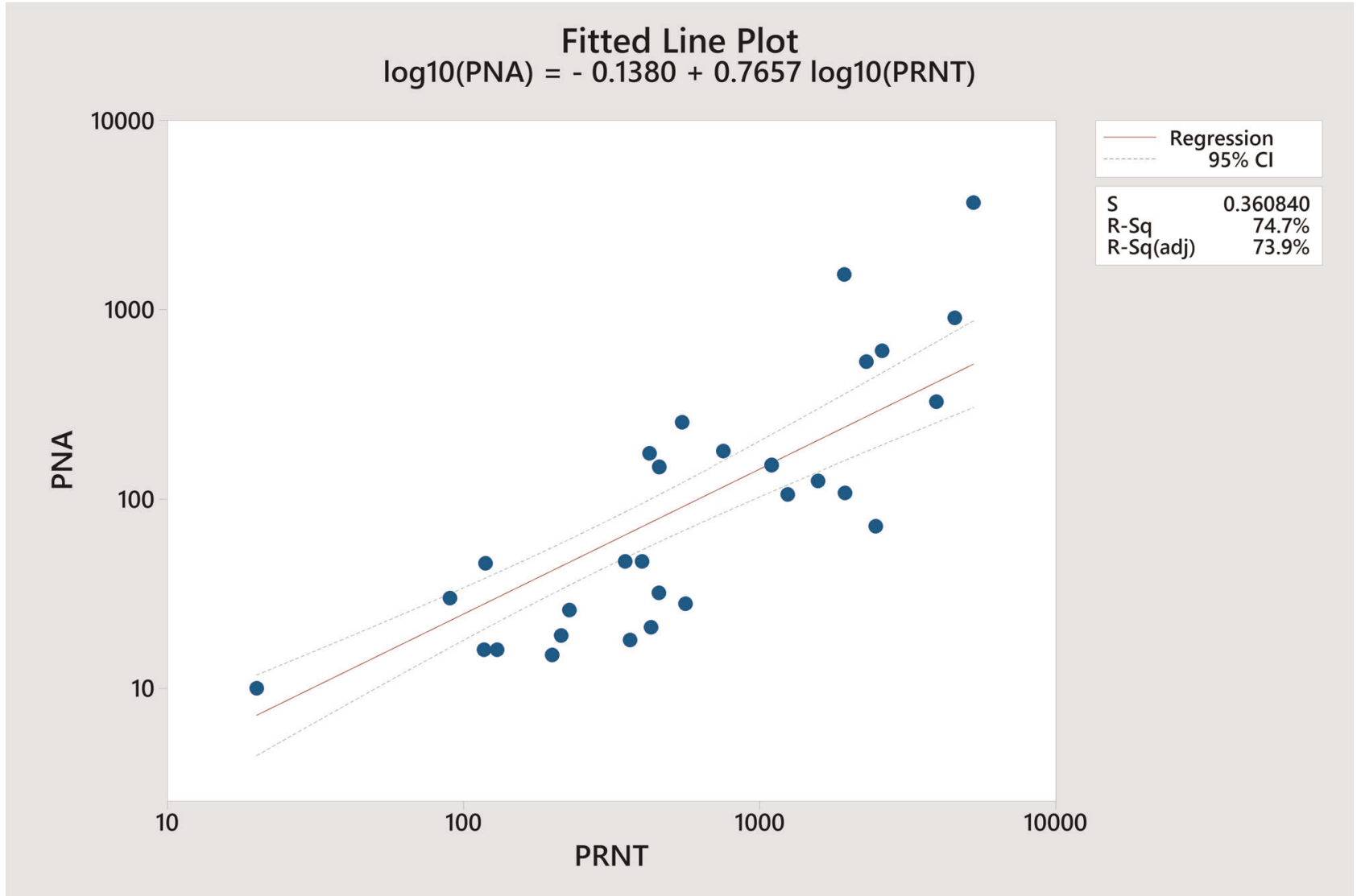

Extended Data Fig. 4 | Showing correlation (MiniTab v19) of the $\mathrm{ND}_{50}$ values of panel of 37 convalescent human sera tested in both PRNT and PNA. The two assays show good correlation (Pearson correlation $r=0.862 ; p<0.001$ ) given that the PRNT is a wild-type virus assay performed at BSL3 with plaques as readout and the other is performed at BSL2 with a pseudotyped virus with a luminescent readout. 


\section{NATURE PROTOCOLS}

PROTOCOL

\begin{tabular}{|c|c|c|c|c|c|c|c|c|c|c|c|c|c|c|c|}
\hline Plate no. & \multicolumn{5}{|c|}{1} & \multicolumn{5}{|c|}{2} & \multicolumn{5}{|c|}{3} \\
\hline Virus Dilution & $1 / 2$ & $1 / 3$ & $1 / 4$ & $1 / 5$ & $1 / 6$ & $1 / 7$ & $1 / 8$ & $1 / 9$ & $1 / 10$ & $1 / 11$ & $1 / 12$ & $1 / 13$ & $1 / 14$ & $1 / 15$ & $1 / 16$ \\
\hline Stock virus ( $\mu \mathrm{l})$ & 250 & 150 & 125 & 100 & 75 & 70 & 75 & 50 & 50 & 40 & 40 & 35 & 35 & 30 & 30 \\
\hline Diluent ( $\mu$ l) & 250 & 300 & 375 & 400 & 375 & 420 & 525 & 400 & 450 & 400 & 440 & 420 & 455 & 420 & 450 \\
\hline Total Volume $(\mu \mathrm{l})$ & 500 & 450 & 500 & 500 & 450 & 490 & 600 & 450 & 500 & 440 & 480 & 455 & 490 & 450 & 480 \\
\hline
\end{tabular}

Extended Data Fig. 5 | Illustration of poor and strongly neutralizing sera in MNA. a, Illustration of a poorly neutralizing/negative (green) serum where the neutralization fails to achieve $50 \%$ of the virus-only control (VOC) at even the lowest dilution tested; b, Illustration of a strongly neutralizing/highly positive (green) serum where the neutralization fails to cross $50 \%$ of the virus-only control (VOC) at the highest dilution tested. 
a

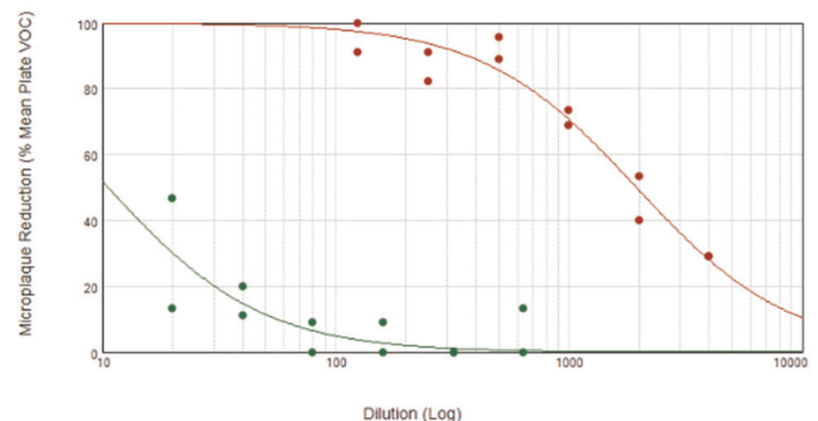

Curve fit: A-parmeter logststic $y=D+\frac{A-D}{1+\left(\frac{x}{C}\right)^{3}}$

Mlot Name Sources $\begin{gathered}\text { Estrmated } \\ \text { Rel. Pot. }\end{gathered}$ std. Errot icso

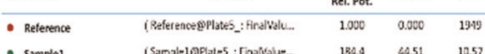

b
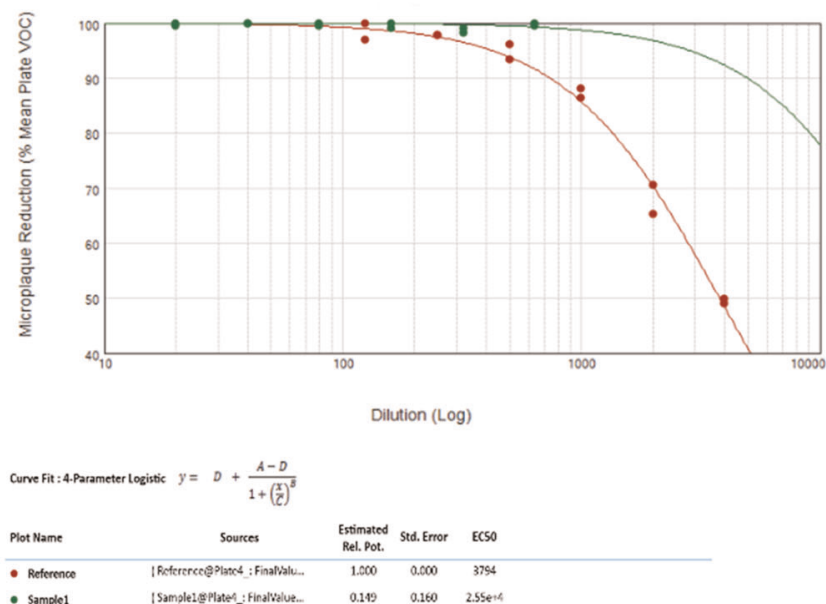

Extended Data Fig. 6 | Volumes required for setup of virus dilutions for fine-sighting experiment of wild-type SARS-CoV-2 prior to PRNT assay. 


\section{Reporting Summary}

Nature Research wishes to improve the reproducibility of the work that we publish. This form provides structure for consistency and transparency in reporting. For further information on Nature Research policies, see our Editorial Policies and the Editorial Policy Checklist.

\section{Statistics}

For all statistical analyses, confirm that the following items are present in the figure legend, table legend, main text, or Methods section.

n/a Confirmed

$\square$ דhe exact sample size $(n)$ for each experimental group/condition, given as a discrete number and unit of measurement

Х $\square$ A statement on whether measurements were taken from distinct samples or whether the same sample was measured repeatedly

$\square$ The statistical test(s) used AND whether they are one- or two-sided

$\bigotimes$ Only common tests should be described solely by name; describe more complex techniques in the Methods section.

$\bigotimes$ A description of all covariates tested

$\square$ \A description of any assumptions or corrections, such as tests of normality and adjustment for multiple comparisons

$\square$ A full description of the statistical parameters including central tendency (e.g. means) or other basic estimates (e.g. regression coefficient)

$\bigotimes$ AND variation (e.g. standard deviation) or associated estimates of uncertainty (e.g. confidence intervals)

$\bigotimes \square \begin{aligned} & \text { For null hypothesis testing, the test statistic (e.g. } F, t, r \text { ) with confidence intervals, effect sizes, degrees of freedom and } P \text { value noted } \\ & \text { Give } P \text { values as exact values whenever suitable. }\end{aligned}$

Х $\square$ For Bayesian analysis, information on the choice of priors and Markov chain Monte Carlo settings

Х $\square$ For hierarchical and complex designs, identification of the appropriate level for tests and full reporting of outcomes

\ $\square$ Estimates of effect sizes (e.g. Cohen's $d$, Pearson's $r$ ), indicating how they were calculated

Our web collection on statistics for biologists contains articles on many of the points above.

\section{Software and code}

Policy information about availability of computer code

Data collection "R" is a free software program for statistical computing and graphics. Version 4 was used in this manuscript for analysis of PRNT data. SoftMax Pro Softwares is a statistical analysis program capable of analysing microplate readouts to GxP standards. Version 7.0.3 was used in this manuscript for analysis of MNA and PNA data.

Data analysis The R script code for analysis of PRNT data has been supplied in the supplementary files. SoftMax Pro code has not been supplied but could be supplied on reasonable request to the authors.

For manuscripts utilizing custom algorithms or software that are central to the research but not yet described in published literature, software must be made available to editors and reviewers. We strongly encourage code deposition in a community repository (e.g. GitHub). See the Nature Research guidelines for submitting code \& software for further information.

\section{Data}

Policy information about availability of data

All manuscripts must include a data availability statement. This statement should provide the following information, where applicable:

- Accession codes, unique identifiers, or web links for publicly available datasets

- A list of figures that have associated raw data

- A description of any restrictions on data availability

The data that support the findings of this study are available from the corresponding author upon reasonable request. Some data are not publicly available due to them containing information that could compromise trial participant privacy/consent. 


\section{Field-specific reporting}

Please select the one below that is the best fit for your research. If you are not sure, read the appropriate sections before making your selection. \Life sciences $\square$ Behavioural \& social sciences Ecological, evolutionary \& environmental sciences

For a reference copy of the document with all sections, see nature.com/documents/nr-reporting-summary-flat.pdf

\section{Life sciences study design}

All studies must disclose on these points even when the disclosure is negative.

Sample size This is discussed and reported in the associated clinical trial publications.

Data exclusions None

Replication During qualification of the MNA; 3 operators, over 3 separate testing days, tested 6 mock-samples to generate the qualification data presented in Extended Data Figure 1.

Randomization In the assay qualification protocol, mock-samples were allocated to plate locations randomly to minimise the impact of edge-effects on results.

Blinding Operators were not blinded to the relative concentrations of the qualification mock-samples - blinding was not possible as the operators produced their own mock-sample panels

\section{Reporting for specific materials, systems and methods}

We require information from authors about some types of materials, experimental systems and methods used in many studies. Here, indicate whether each material, system or method listed is relevant to your study. If you are not sure if a list item applies to your research, read the appropriate section before selecting a response.

Materials \& experimental systems

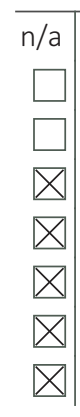

n/a Involved in the study

$\bigotimes$ Antibodies

$\bigotimes$ Eukaryotic cell lines

\ $\square$ Palaeontology and archaeology

Х $\square$ Animals and other organisms

Х $\square$ Human research participants

$\bigotimes \square$ Clinical data

$\bigotimes \mid \square$ Dual use research of concern

\section{Antibodies}

Antibodies used

Validation
Anti-Spike Rabbit Polyclonal antibody (Sino Biologicals; 40592-T62)

Manufacturer states some cross-reactivity with SARS-CoV Spike S1 and RBD. The authors have demonstrated satisfactory virus foci staining with variants including Victoria/1/2020, B.1.1.7, B.1.351 and SARS-CoV-2 cluster 5.

\section{Eukaryotic cell lines}

\section{Policy information about cell lines}

Cell line source(s)

Authentication

Mycoplasma contamination

Commonly misidentified lines (See $\underline{I C L A C}$ register)
Vero E6 (ECACC), Vero hSLAM (ECACC)

Speciated by DNA barcoded sequencing of the mitochondria cytochrome c oxidase subunit 1 gene by ECACC

Tested by PCR and Hoechst 33258 by ECACC; mycoplasma not detected

None listed in ICLAC register for Vero 